\title{
Seed Set Patterns in East African Highland Cooking Bananas Show Asymmetric Distribution in Bunches and Fruits
}

\author{
Allan Waniale ${ }^{1,2, *(D)}$, Rony Swennen ${ }^{3,4} \mathbb{D}$, Settumba B. Mukasa ${ }^{1}$, Arthur K. Tugume ${ }^{5}$, Jerome Kubiriba ${ }^{2}$, \\ Wilberforce K. Tushemereirwe ${ }^{2}$, Michael Batte ${ }^{6}$, Allan Brown ${ }^{3}$ and Robooni Tumuhimbise ${ }^{7, * \text { (D) }}$ \\ 1 Department of Agricultural Production, College of Agricultural and Environmental Sciences, \\ Makerere University, Kampala P.O. Box 7062, Uganda; sbmukasa@caes.mak.ac.ug \\ 2 National Agricultural Research Laboratories, Kawanda, Kampala P.O. Box 7065, Uganda; \\ jkubiriba2012@gmail.com (J.K.); tkwilberforce@gmail.com (W.K.T.) \\ 3 International Institute of Tropical Agriculture, c/o Nelson Mandela African Institution of Science and \\ Technology, Arusha, Tanzania; rony.swennen@kuleuven.be (R.S.); A.Brown@cgiar.org (A.B.) \\ 4 Department of Biosystems, KU Leuven, W. De Croylaan 42, 3001 Heverlee, Belgium \\ 5 Department of Plant Sciences, Microbiology and Biotechnology, College of Natural Sciences, \\ Makerere University, Kampala P.O. Box 7062, Uganda; arthur.tugume@mak.ac.ug \\ 6 International Institute of Tropical Agriculture, Kampala P.O. Box 7878, Uganda; M.Batte@cgiar.org \\ 7 Rwebitaba Zonal Agricultural Research and Development Institute, Fort Portal P.O. Box 96, Uganda \\ * Correspondence: allanwaniale@gmail.com (A.W.); rtumuhimbise@hotmail.com (R.T.)
}

\section{check for} updates

Citation: Waniale, A.; Swennen, R.; Mukasa, S.B.; Tugume, A.K.;

Kubiriba, J.; Tushemereirwe, W.K.;

Batte, M.; Brown, A.; Tumuhimbise, R.

Seed Set Patterns in East African

Highland Cooking Bananas Show Asymmetric Distribution in Bunches and Fruits. Agronomy 2021, 11, 763. https://doi.org/10.3390/

agronomy11040763

Academic Editor: Francis Drummond

Received: 21 March 2021

Accepted: 12 April 2021

Published: 14 April 2021

Publisher's Note: MDPI stays neutral with regard to jurisdictional claims in published maps and institutional affiliations.

Copyright: (c) 2021 by the authors. Licensee MDPI, Basel, Switzerland. This article is an open access article distributed under the terms and conditions of the Creative Commons Attribution (CC BY) license (https:// creativecommons.org/licenses/by/ $4.0 /)$.
Abstract: Low female fertility in bananas is the biggest hurdle for banana breeding. The aim of this study was to determine seed set patterns in East African Highland Cooking bananas (EAHBs) to inform future decisions on a more targeted approach of increasing seed set and subsequently banana-breeding efficiency. Matooke (AAA) and Mchare (AA) bananas are genetically distinct but belong to the same genetic complex, referred to as EAHBs. Seed set patterns in "Enzirabahima" (AAA), "Mshale" (AA), and "Nshonowa" (AA), all with residual fertility, were examined after hand pollination with a highly male fertile wild banana "Calcutta 4" (AA). Seed set in "Enzirabahima" is predominant in distal hands. Mchare cultivars have a slightly more even distribution of seeds in their hands compared to "Enzirabahima". There is a gradual increase in seed set from proximal to distal hands with a slight drop in the last hand. This pattern is more definite in "Enzirabahima" and "Mshale", while "Nshonowa" has a somewhat inconsistent pattern. There is also a drop in seed set per 100 fruits per hand from small to larger bunches. However, larger bunches have a higher pollination success compared to smaller bunches. They therefore set more seed on 100 fruits per hand and per bunch basis, if bunches without seed are accounted for. Pollination success rate increases from smaller to larger bunches of EAHBs. Seed set is biased toward the distal third part of fruits of examined EAHBs, as well as tetraploid Matooke hybrid "401K-1" (AAAA), and improved diploid "Zebrina" GF (AA) that were used for comparison. In comparison, in the highly female fertile "Calcutta 4", seed set is along the entire length of the fruit. Seed set bias in the distal hands and distal end of fruits suggests a systematic mechanism rather than a random occurrence. It is expected that this information will provide a foundation for increased crossbreeding efficiency in bananas.

Keywords: female fertility; banana breeding; Matooke and Mchare pollination; bunch size; pollination success

\section{Introduction}

Bananas (Musa ssp.), including plantains, are the world's most popular fruit crop grown in about 130 tropical and subtropical countries on an estimated 11 million hectares [1] Though grown in the tropics and subtropics, their origin is traced back to Southeast Asian and Western Pacific regions, where their wild relatives exist in natural forests [2]. Bananas are also the only fruit crop that is a staple food for many farming communities in the tropics. Overall banana production (excluding plantains and others) was estimated 
at 129 million tons in 2019 [1], with only 16\% exported [3], and the rest was locally consumed. Latin America and the Caribbean accounted for $72 \%$ of all exported bananas, Africa accounted for $4 \%$, and the rest came from Asia [3]. The East African region produced close to 17 million tons of bananas (including plantains and others) in 2019 [1] with negligible export.

The dominant banana type in the Great Lakes region of East Africa is the East African Highland bananas commonly known as Matooke (AAA) [4]. They are grown in Kenya, Uganda, Tanzania, Rwanda, Burundi, and the eastern part of the Democratic Republic of Congo [4]. There are about 120 Matooke triploids, which are further classified into clone sets, including Mbidde (beer type), Musakala, Nakabululu, Nakitembe, and Nfuuka [4,5]. The highly starchy Matooke fruits are mainly consumed in steamed and mashed form, or they are ripened and brewed into banana beer for the beer type [4,6]. The Mchare subgroup (AA), which is genetically distinct from Matooke, is common in Tanzania [7]. They share the same AA genome with "Gros Michel" and Cavendish triploid bananas [8]. Mchare are genetically homogenous but adapted to wider ecological environments ranging from sealevel to elevations above 1500 m.a.s.l. [9]. They are grown from islands of Zanzibar, Pemba, off the East African coast to the main land of Tanzania, Kenya, and Central Uganda [4]. Mchare bananas are classified by FAO as dessert bananas, but they are mainly consumed as cooked [4] or roasted in the Kilimanjaro region [9]. Matooke and Mchare can therefore be collectively referred to as East African Highland Cooking bananas (EAHBs). They belong to the same genetic complex transported from South-East Asia [10].

From the 1970s, banana production in East Africa experienced a drop attributed largely to a complex of diseases (fungal, bacterial, and viral), nematodes, and insect pests [11]. Low production and productivity is also attributed to poor agronomic practices; abiotic stresses, including poor edaphic factors; and an imminent threat of climate change [12]. Most banana-breeding programs therefore focus on these production constraints when defining their breeding goals. The major stumbling block to crossbreeding in bananas is low seed set [6]. Reference [13] reported an average of 303 ovules per fruit in Matooke, yet the seed set range was only 0-25 per bunch. This implies that an average sized Matooke bunch with 100 fruits could potentially yield over 30,000 seeds. A total of 78 Matooke landraces were screened in Uganda, of which 37 were considered to be seed fertile [13]. On the other hand, Mchare have not been well characterized, especially for female fertility. The reasons for low seed set are a complex array of factors that have hindered efficient banana breeding. For the triploid bananas, including Matooke, female sterility as a result of meiotic failures has been a major obstacle [6]. Some cultivars, including those of the Matooke, are rendered "infertile" [14]; thus, improvement of such cultivars by conventional means is difficult.

Nevertheless, female sterility has also been observed among diploid bananas [15], suggesting factors beyond meiotic failures contribute to sterility. For example, successful pollination can be achieved when flowers of "Gros Michel" bananas are pollinated between 7:00 a.m. and 10:30 a.m. [16]. To unveil the mystery of overcoming sterility in Musa, responsible factors have to be dealt with comprehensively to have a better perspective. In most analyses in Musa, seed set is considered on a bunch basis. However, bunch size for the same genotype varies depending on environmental and soil fertility factors [17]. Intriguingly, analyses by Reference [18] strongly suggested a relationship between bunch size and seed set, with larger bunches setting more seed on a seed set per 100 fruits basis. Furthermore, significant differences in seed set for hand position have been observed in Matooke, and this was linked to stigma receptivity [19]. Distal hands were found to have more receptive stigmas than proximal hands thus the higher fertility in distal hands. In plantains, seed set also depends on hand position [20], and there is a general tendency of seed set in the middle hands for both plantain and Matooke. In addition, seed set in "Gros Michel" was found to be predominant in the distal end of the fruit rather than the proximal end [18]. 
These observations have not been made on an individual bunch-size basis, especially in EAHBs, and there is a need to look into the behavior of seed set position in hands of different bunch sizes. Correlation coefficients between seed set and weather attributes are mostly less than 0.5 [21]. This suggests that there are more factors that are yet to be identified and considered. Reference [22] also found no month effects for pollination success of Matooke after 21 years of crossbreeding. This raises questions about the underlying causes of observations made and how understanding these factors can ultimately lead to overcoming the fertility crisis in Musa. The aim of this study was to investigate seed set patterns in hands of the bunch, number of fruits per hand in different bunch sizes, seed set position in the fruits, and pollination success in relation to bunch size of EAHBs. Seed set patterns were also compared for different pollination techniques used. The data generated will inform future decisions, on a more targeted approach, of increasing seed set in edible bananas and facilitating banana breeding.

\section{Materials and Methods}

\subsection{Banana Genotypes Used and Study Site}

Musa (AAA group, Matooke subgroup) "Enzirabahima” and Musa (AA group, Mchare subgroup) "Mshale" and "Nshonowa" with residual female fertility were used as female parents. Musa (AAA group, Matooke subgroup) "Nakitembe" and Musa (AA group, Mchare subgroup) "Mlelembo" were also pollinated along with the first three cultivars. Only one bunch of "Nakitembe" set one seed while "Mlelembo" set two seeds in the same bunch, over 200 bunches of each of these two cultivars were made. Because of the extreme low fertility, "Nakitembe" and "Mlelembo" were not considered for seed set patterns in EAHBs. Matooke and Mchare banana groups are referred to as EAHBs with reference to their utilization. A highly pollen fertile Musa acuminata ssp. burmannicoides ("Calcutta 4") wild banana was used as a male parent.

Each female parent was planted in a pollination block with 9 mats within columns and 22 mats within rows to yield a total of 198 mats. A spacing of $3 \mathrm{~m}$ between rows and $2 \mathrm{~m}$ between mats in columns was used which gave a density of 1666 mats / ha. The male parent "Calcutta 4" was planted in columns separating female parents. Improved diploid "Zebrina GF" (AA) and tetraploid Matooke hybrid "401K-1" (AAAA) from other pollination blocks were used for comparison with EAHBs seed set patterns in fruits. The study was conducted at the National Agricultural Research Laboratories (NARL), Kawanda. NARL is located at latitude $0^{\circ} 25^{\prime} \mathrm{N}$, longitude $32^{\circ} 32^{\prime} \mathrm{E}$, at an elevation of $1177 \mathrm{~m}$ above sea level.

\subsection{Pollination Techniques and Procedure}

Different pollination techniques were used; these include, hand pollination, as described by Reference [23] (technique 1 or control). Technique 1 was modified by applying pollen germination media (PGM) on stigmas after dusting pollen (technique 2 ). The third technique involved early pollination by forcing bracts open about a day before opening with PGM application on stigmas after dusting pollen (Figure 1). The third pollination technique was explored between June 2016 and February 2018. The fourth and last technique was evening pollinations after natural bract opening with PGM application on stigmas after dusting pollen. This was also explored between June 2016 and June 2017. These pollination techniques were performed on different bunches as they emerged. They were geared towards increasing seed set, but the focus here is seed set patterns.

Pollen germination media was applied with the aim of enhancing stigma receptivity for maximum pollen germination as demonstrated in our earlier work [24]. Using tap water, PGM was prepared using $30 \mathrm{~g} / \mathrm{L}$ glucose as a substitute for sucrose, along with other compounds as described by Reference [25] and boric acid at $0.1 \mathrm{~g} / \mathrm{L}$. The PGM used for pollinations in 2016 was $30 \mathrm{~g} / \mathrm{L}$ glucose and complete PGM in the rest of the pollinations. The PGM was applied to pollen dusted on stigmas in a fine mist, using a hand-spray pump before re-bagging (Figure 1). The three cultivars had varying days from initial pollination to full maturity, "Enzirabahima" matured in 98 days, "Mshale" in 131 days, 
and "Nshonowa" in 135 days. On the other hand, "Nakitembe" and "Mlelembo" matured in 96 and 130 days, respectively.

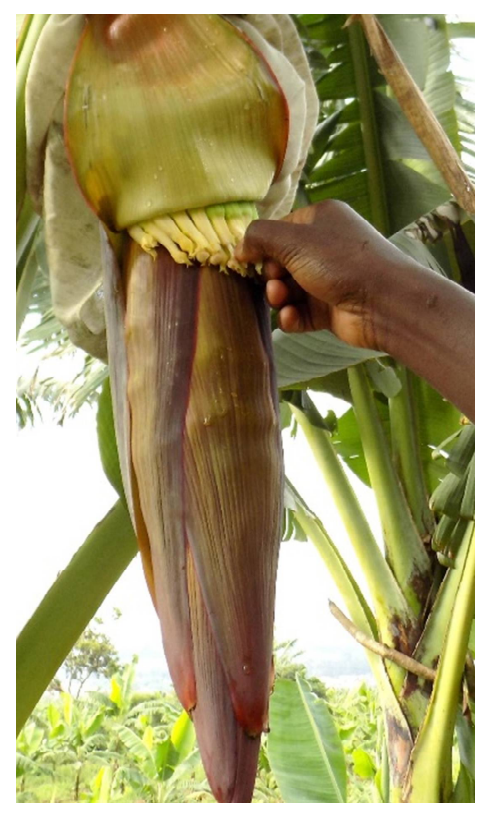

(a)

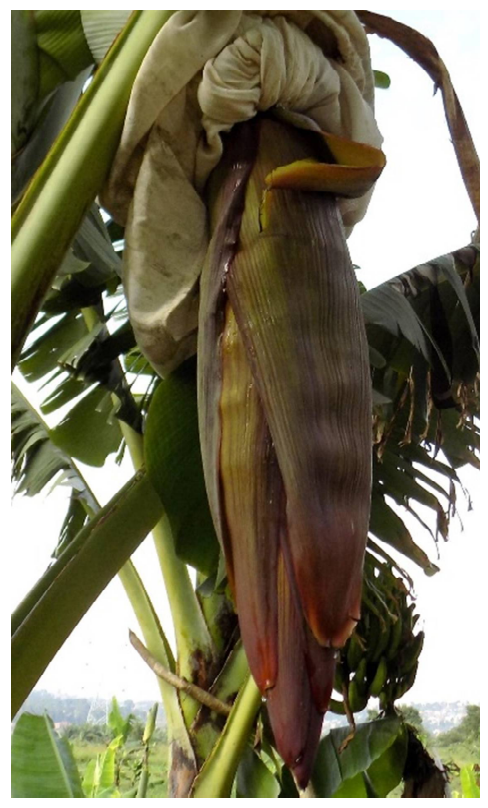

(d)

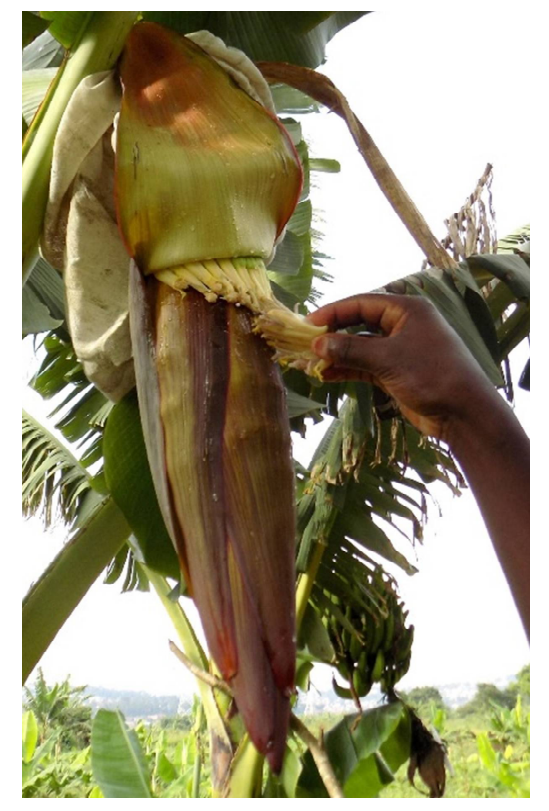

(b)

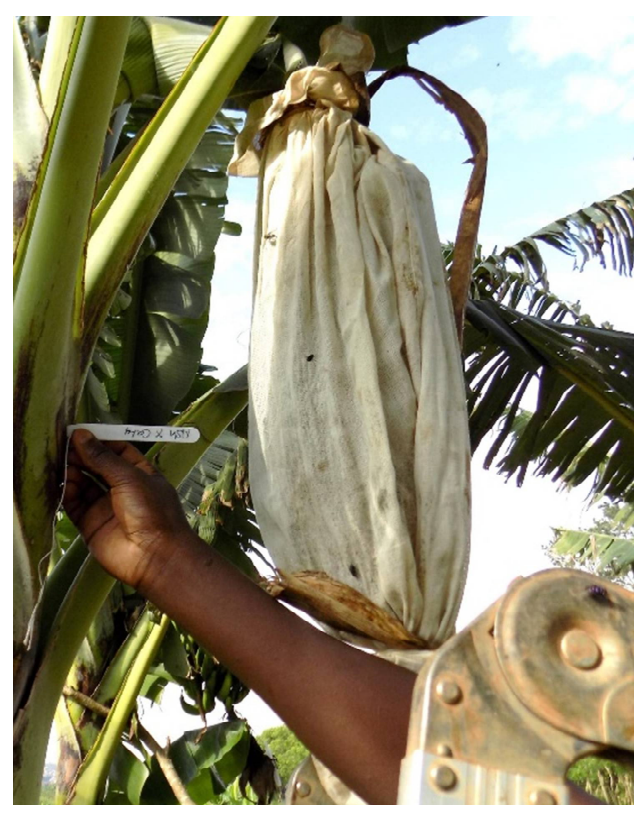

(e)

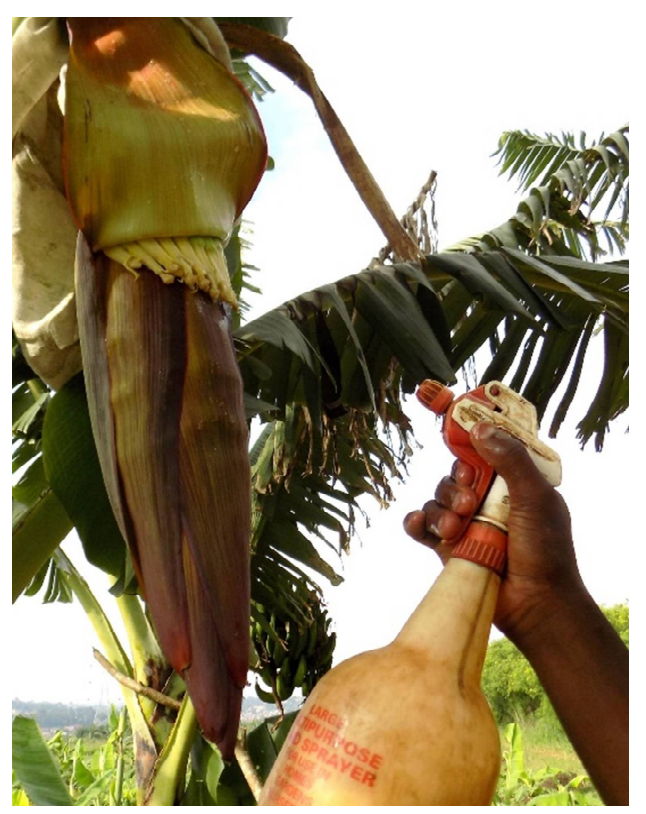

(c)

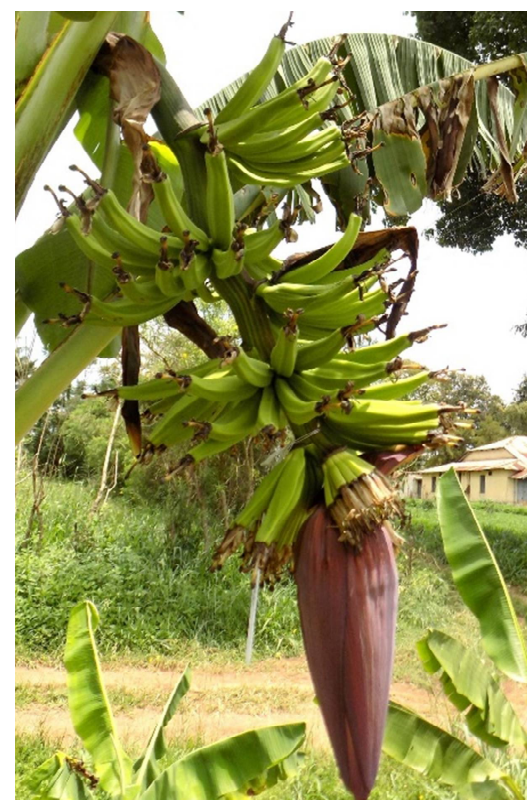

(f)

Figure 1. Procedure of early pollination (technique 3) on Musa (AA group subgroup Mchare) "Nshonowa": (a) flower bract forced open and tepals removed to expose stigmas for pollination; (b) an excised hand of male flowers rubbed on stigmas to apply pollen; (c) pollen germination media (PGM) solution applied with hand sprayer; (d) flower bract returned in position; (e) inflorescence re-bagged and labeled with names of parents, cross ID, and initial date of pollination. Except labeling, steps from A to E are repeated for pollination of next hand when it is ready; and (f) pollinated bunch left to mature in the open.

\subsection{Data Handling}

At full maturity, when at least one finger started ripening, bunches were harvested and kept in a ripening room, and seeds were hand-extracted, washed, air-dried, and counted. The total number of seeds per hand was recorded for each cultivar and each 
bunch. The number of fruits per hand was also recorded. For each cultivar, bunch sizes were categorized based on number of hands per bunch, and percentage seed set was calculated for different hands and different bunch sizes as follows:

$$
\frac{\text { Total number of seeds per hand position for a given bunch size category }}{\text { Total number of seeds for a given bunch size category }} \times 100 \%
$$

pollination success rate was calculated as follows;

$$
\frac{\text { Total number of bunches with seed for a given bunch size category }}{\text { Total number of pollinated bunches for a given bunch size category }} \times 100 \%
$$

analysis of variance (ANOVA) on number of fruits per hand for different bunch sizes of the three cultivars was done by using Genstat, 19th Edition developed by VSN International (VSNi). Fruits per hand were taken as treatment with total bunches as replicates. The number of hands in a bunch category was therefore the treatment factor, and different categories were analyzed separately. The ANOVA model used was as follows:

$$
\text { Fruits per hand }=\text { Mean }+ \text { Treatment }+ \text { Error }
$$

seed set per bunch was adjusted to seed set per 100 fruits of each bunch for equal footing comparison of bunches with different total fruits and hands. The adjustment was made as follows:

$$
\frac{\text { Total seed in a bunch }}{\text { Total number of fruits of that bunch }} \times 100
$$

to compare seed set of different hand positions on equal footing, average seed set per hand was adjusted to seed set per 100 fruits of that hand. Only bunches with seeds were considered in the calculation. The adjustment was made for the three cultivars and all bunch sizes as follows:

$$
\frac{\text { Average seed of hand position }}{\text { Average number of fruits of that hand position }} \times 100
$$

where average seed of hand position was calculated as follows:

$$
\frac{\text { Total seed of hand position }}{\text { Number of bunch with seed }}
$$

seed set per 100 fruits per hand was plotted against hand position for different bunch size categories of the same cultivar on the same plot.

Chi-square goodness of fit $\left(\mathrm{X}^{2}{ }_{\text {cal }}\right)$ for seed set in hand positions was calculated as follows:

$$
\sum \frac{(\text { Observed seed per hand }- \text { Expected seed per hand })^{2}}{\text { Expected seed per hand }}
$$

where observed seed per hand is the number of seed in given hand position for all fertile bunches. Expected seed per hand of a particular bunch-size category and cultivar was calculated as follows:

$$
\frac{\text { Average fruits per hand for that hand position }}{\text { Average fruits per bunch }} \times \text { Total seed }
$$

degrees of freedom for the Chi-square test are the number of hands in bunch-size category minus one. Chi probability $\left(\mathrm{X}^{2}\right.$ prob) was taken as the right tailed Chi probability. The position of seed set in the fruit pulp was observed by carefully splitting open pollinated ripe fruits of "Mshale", "Nshonowa" and "Enzirabahima", in comparison to the tetraploid Matooke hybrid "401K-1" (AAAA). Seed set positions of pollinated partially parthenocarpic improved diploid "Zebrina GF" (AA) and in the non-parthenocarpic open pollinated wild 
banana "Calcutta 4" (AA) were also observed for comparison with EAHBs. Selected pictures of seed set position in fruits are presented.

\section{Results}

\subsection{Percentage Seed Set per Hand and Fruits per Hand}

Irrespective of the pollination technique used, seed set pattern was similar within bunch size categories among the three female fertile EAHBs. Data of different pollination techniques and same bunch size categories were therefore merged for the respective cultivars (Appendix A Tables A1-A3). For "Enzirabahima", maximal seed set was observed in the second-last hand of the four-, five-, and seven-hand bunches (Table 1).

Table 1. Percentage seed set per hand and by number of hands per bunch in "Enzirabahima", "Mshale", and "Nshonowa".

\begin{tabular}{|c|c|c|c|c|c|c|c|c|c|c|c|c|c|}
\hline \multirow{2}{*}{ Cultivar } & \multirow{2}{*}{$\begin{array}{l}\text { Bunches } \\
\text { with Seed }\end{array}$} & \multirow{2}{*}{$\begin{array}{c}\text { Bunch Size } \\
\text { (Hands) }\end{array}$} & \multirow{2}{*}{$\begin{array}{l}\text { Total } \\
\text { Seed }\end{array}$} & \multicolumn{10}{|c|}{ Seed Set per Hand (\%) } \\
\hline & & & & 1 & 2 & 3 & 4 & 5 & 6 & 7 & 8 & 9 & 10 \\
\hline \multirow{5}{*}{$\begin{array}{l}\text { “Enzirabahima” } \\
\text { (AAA) }\end{array}$} & 6 & 4 & 27 & 3.7 & 22.2 & 44.4 & 29.6 & & & & & & \\
\hline & 23 & 5 & 89 & 0.0 & 4.5 & 28.1 & 34.8 & 32.6 & & & & & \\
\hline & 43 & 6 & 243 & 1.6 & 10.7 & 15.2 & 30.5 & 22.6 & 19.3 & & & & \\
\hline & 34 & 7 & 210 & 0.0 & 5.2 & 15.2 & 14.8 & 25.7 & 27.1 & 11.9 & & & \\
\hline & 7 & 8 & 28 & 0.0 & 10.7 & 10.7 & 32.1 & 7.1 & 21.4 & 10.7 & 7.1 & & \\
\hline \multirow{6}{*}{ “Mshale" (AA) } & 2 & 4 & 42 & 11.9 & 38.1 & 31.0 & 19.0 & & & & & & \\
\hline & 31 & 5 & 610 & 5.7 & 17.2 & 24.1 & 24.6 & 28.4 & & & & & \\
\hline & 47 & 6 & 961 & 5.5 & 8.3 & 19.7 & 22.8 & 24.2 & 19.5 & & & & \\
\hline & 29 & 7 & 1193 & 10.9 & 18.3 & 17.5 & 17.5 & 15.8 & 10.7 & 9.3 & & & \\
\hline & 4 & 8 & 67 & 0.0 & 7.5 & 13.4 & 9.0 & 28.4 & 26.9 & 10.4 & 4.5 & & \\
\hline & 1 & 10 & 66 & 6.1 & 43.9 & 19.7 & 12.1 & 12.1 & 6.1 & 0.0 & 0.0 & 0.0 & 0.0 \\
\hline \multirow{7}{*}{$\begin{array}{c}\text { "Nshonowa" } \\
\text { (AA) }\end{array}$} & 1 & 4 & 2 & 0.0 & 0.0 & 0.0 & 100.0 & & & & & & \\
\hline & 10 & 5 & 39 & 0.0 & 15.4 & 25.6 & 20.5 & 38.5 & & & & & \\
\hline & 11 & 6 & 90 & 4.4 & 22.2 & 22.2 & 26.7 & 17.8 & 6.7 & & & & \\
\hline & 17 & 7 & 234 & 15.8 & 16.2 & 11.1 & 12.8 & 16.2 & 10.3 & 17.5 & & & \\
\hline & 14 & 8 & 237 & 3.4 & 3.4 & 8.4 & 10.1 & 15.6 & 16.9 & 35.4 & 6.8 & & \\
\hline & 3 & 9 & 36 & 0.0 & 27.8 & 0.0 & 0.0 & 2.8 & 25.0 & 8.3 & 2.8 & 33.3 & \\
\hline & 3 & 10 & 29 & 3.4 & 10.3 & 0.0 & 6.9 & 17.2 & 17.2 & 24.1 & 0.0 & 3.4 & 17.2 \\
\hline
\end{tabular}

The six- and eight-hand bunches had maximal seed set in the third last and fourth hand respectively. There was generally less seed set in the first two hands of "Enzirabahima" with no seed in the first hands of five-, seven-, and eight-hand bunches. Seed set increase in "Enzirabahima" was observed after pollination with PGM. However, the increase happened in the same fertile hand positions as of bunches pollinated without PGM (Appendix A Table A1). There were no embryos in seeds from the "Nakitembe" and "Mlelembo" bunches that set one and two seeds per bunch, respectively.

In "Mshale" and "Nshonowa", there was generally a more even seed set among middle hands with the proximal and distal hands having fewer seeds per hand on a percentage seed set basis. Mchare cultivars had seven-hand bunches with relatively even seed set across all hands. Unlike "Enzirabahima", five-hand bunches of Mchare were observed to set maximal number of seeds in last hand with female fruits. Similar results were obtained by Reference [20] for seed set in plantain (Musa AAB group), especially in cultivar "Obino I'Ewai". Smaller bunches had the highest seed set in the middle hands, whereas larger bunches had a slight shift of maximal seed set to the distal hands (Table 1). Though fewer Mchare bunches were pollinated in comparison with "Enzirabahima", they had relatively higher pollination success (Appendix A Tables A1-A3). Generally, there was an increase in average seed set rates per 100 fruits, as well as success rate from small to larger bunches, in the three EAHB cultivars (Appendix A Tables A1-A3).

Mchare cultivars had a higher seed set range of 0 to 261 per bunch compared to the range in "Enzirabahima" of 0 to 33 (Appendix A Tables A1-A3). For Mchare, "Mshale" had a higher seed set range of 0 to 261 per bunch than that of "Nshonowa" with 0 to 
85 seeds. The highest seed set per bunch in "Mshale" was from a seven-hand bunch, from an eight-hand bunch in "Nshonowa" while for "Enzirabahima", a six-hand bunch had the highest. Strangely, there were hyper increases of seed set in a few bunches which could not be replicated in same size bunches of the same cultivars pollinated about the same time. This prompted an investigation of the features around the mats where such bunches grew. Interestingly, such mats were on pockets of poor soil with some pebbles.

There were significant differences for number of fruits per hand among "Enzirabahima", "Mshale", and "Nshonowa" bunches of different sizes (Table 2). Number of fruits in the last hand with female fruits of all different sized bunches evaluated were significantly lower than in other hands. The exception was the four-hand category of "Nshonowa", which was non-significant, even if there was a difference of five fruits between the proximal and distal hands. The number of fruits per hand, however, seemed not to account for highest seed set in the distal hands as there was a gradual decrease of fruits per hand from proximal to distal hands. With these differences in fruits per hand position, a better approach of comparing seed set between hands was a prerequisite.

Table 2. Mean fruits per hand for different bunch sizes of "Enzirabahima", "Mshale", and "Nshonowa".

\begin{tabular}{|c|c|c|c|c|c|c|c|c|c|c|c|}
\hline \multirow{2}{*}{ Cultivar } & \multirow{2}{*}{$\begin{array}{l}\text { Bunch Size } \\
\text { (Hands) }\end{array}$} & \multirow{2}{*}{$\begin{array}{c}\text { Number of } \\
\text { Bunches }\end{array}$} & \multicolumn{8}{|c|}{ Fruits per Hand } & \multirow{2}{*}{ F-Pro } \\
\hline & & & 1 & 2 & 3 & 4 & 5 & 6 & 7 & 8 & \\
\hline \multirow{5}{*}{$\begin{array}{c}\text { "Enzirabahima" } \\
\text { (AAA) }\end{array}$} & 4 & 39 & $12.3 a$ & $11.7 \mathrm{a}$ & $10.9 a$ & $9.0 \mathrm{~b}$ & & & & & $<0.001$ \\
\hline & 5 & 107 & $14.3 a$ & $14.2 \mathrm{a}$ & $13.1 \mathrm{~b}$ & $12.2 \mathrm{c}$ & $10.0 \mathrm{~d}$ & & & & $<0.001$ \\
\hline & 6 & 103 & $14.6 \mathrm{ab}$ & $15.3 \mathrm{a}$ & $14.1 b c$ & $13.5 \mathrm{c}$ & $12.0 \mathrm{~d}$ & $8.5 \mathrm{e}$ & & & $<0.001$ \\
\hline & 7 & 52 & $14.7 \mathrm{ab}$ & $15.6 \mathrm{a}$ & $15.0 \mathrm{ab}$ & $14.2 \mathrm{bc}$ & $13.2 \mathrm{c}$ & $11.9 \mathrm{~d}$ & $7.3 \mathrm{e}$ & & $<0.001$ \\
\hline & 8 & 4 & $18.8 \mathrm{a}$ & $18.8 \mathrm{a}$ & $17.3 \mathrm{ab}$ & $17.0 \mathrm{ab}$ & $15.3 b$ & $15.3 b$ & $12.5 c$ & $8.5 \mathrm{~d}$ & $<0.001$ \\
\hline \multirow{5}{*}{ “Mshale" (AA) } & 4 & 5 & $15.0 \mathrm{a}$ & $14.2 \mathrm{ab}$ & $13.0 \mathrm{~b}$ & $11.2 \mathrm{c}$ & & & & & $<0.001$ \\
\hline & 5 & 63 & $16.1 \mathrm{a}$ & $15.9 \mathrm{a}$ & $14.9 \mathrm{~b}$ & $13.4 \mathrm{c}$ & $11.6 \mathrm{~d}$ & & & & $<0.001$ \\
\hline & 6 & 46 & $15.4 \mathrm{a}$ & $15.2 \mathrm{a}$ & $14.2 \mathrm{ab}$ & $13.4 \mathrm{bc}$ & $12.4 \mathrm{c}$ & $11.1 d$ & & & $<0.001$ \\
\hline & 7 & 15 & $14.2 \mathrm{a}$ & $14.4 \mathrm{a}$ & $13.7 \mathrm{ab}$ & $12.9 \mathrm{ab}$ & $12.3 \mathrm{ab}$ & $11.3 b c$ & $9.7 c$ & & 0.004 \\
\hline & 8 & 3 & $17.7 \mathrm{a}$ & $17.7 \mathrm{a}$ & $16.3 \mathrm{ab}$ & $14.3 \mathrm{bc}$ & $14.7 \mathrm{abc}$ & $12.7 \mathrm{~cd}$ & $11.7 \mathrm{~cd}$ & $10.7 \mathrm{~d}$ & 0.002 \\
\hline \multirow{5}{*}{ “Nshonowa" (AA) } & 4 & 9 & $14.0 \mathrm{a}$ & $12.7 \mathrm{a}$ & $11.1 \mathrm{a}$ & $9.3 a$ & & & & & 0.143 \\
\hline & 5 & 52 & $16.8 \mathrm{a}$ & $16.2 \mathrm{a}$ & $14.7 \mathrm{~b}$ & $13.4 \mathrm{c}$ & $11.7 \mathrm{~d}$ & & & & $<0.001$ \\
\hline & 6 & 35 & $17.1 \mathrm{a}$ & $16.7 \mathrm{ab}$ & $15.4 \mathrm{bc}$ & $14.3 \mathrm{~cd}$ & $13.4 \mathrm{~d}$ & $11.1 \mathrm{e}$ & & & $<0.001$ \\
\hline & 7 & 20 & $14.7 \mathrm{a}$ & $14.7 \mathrm{a}$ & $13.4 \mathrm{ab}$ & $12.8 \mathrm{bc}$ & $12.0 \mathrm{bc}$ & $11.6 \mathrm{~cd}$ & $9.8 \mathrm{~d}$ & & $<0.001$ \\
\hline & 8 & 12 & $15.9 a$ & $15.5 \mathrm{a}$ & $14.8 \mathrm{ab}$ & $14.3 \mathrm{abc}$ & $13.6 a b c$ & $12.5 \mathrm{bc}$ & $11.5 \mathrm{~cd}$ & $9.3 \mathrm{~d}$ & $<0.001$ \\
\hline
\end{tabular}

Means with different letters across the row are statistically different. F-pro $=$ F probability.

\subsection{Average Seed Set per 100 Fruits per Hand}

In "Enzirabahima", seed set per 100 fruits per hand followed a hyperbolic pattern for all bunch sizes from proximal to distal hands (Figure 2). For all bunch sizes, proximal hands had less seed set which gradually increased in hands that followed and slightly dropped in last hand with female fruits. Small sized bunches had higher seed set per 100 fruits per hand, and this gradually reduced with increased bunch size. "Mshale" had a similar pattern as "Enzirabahima", with the exception of seven-hand-bunch category, which had the most seed in proximal hand (Figure 3). The "Mshale" curve for seven-hand-bunch category had highest averages partly because of a single bunch that had 261 seeds. For both "Mshale" and "Enzirabahima", the four-hand bunches experienced the biggest drop in seed set in the last hand. "Nshonowa" did not have a consistent pattern as five-, seven-, and nine-hand-bunch categories had positive "a" coefficients of the quadratic equation (Figure 4 and Table 3). With the exception of five-hand-bunch category of "Nshonowa", bunches with six or less hands had high $\mathrm{R}^{2}$ values (Table 3 ). These observations were as a result of few bunches used to calculate means especially for the 9- and 10-hand-bunch categories which had three bunches with seed each. The 9- and 10-hands categories were therefore excluded from the plot (Figure 3). A chi-square test for goodness of fit revealed 
that observed number of seed was significantly different from expected number except in "Mshale" of four hands per bunch category (Appendix B Table A4).

\subsection{Seed Set Position in Fruits}

For fruits which set seed among female fertile EAHBs predominantly set seed in the distal one third of the fruit, especially when there were no more than 3 seeds (Figure 5a). The same pattern was observed in "401K-1" (AAAA) and "Zebrina GF" (AA) that are used in breeding. In the event of multiple seed set in a fruit (more than 3 ), seeds were distributed in the distal half of the fruit (Figure 5b). This was observed mainly in Mchare. On the contrary, open pollinated wild banana "Calcutta 4" set seed over the entire length of the fruit (Figure 5c).

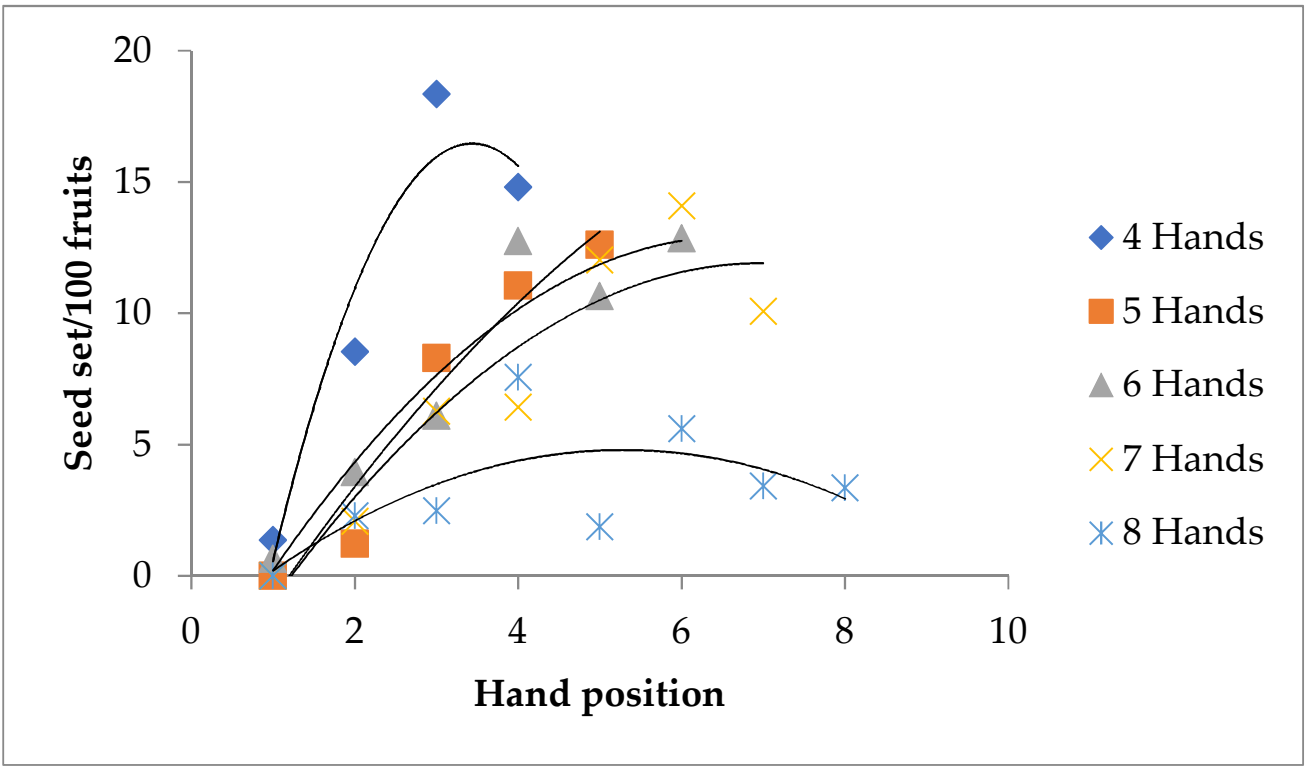

Figure 2. Seed set per 100 fruit per hand in different sized bunches of "Enzirabahima".

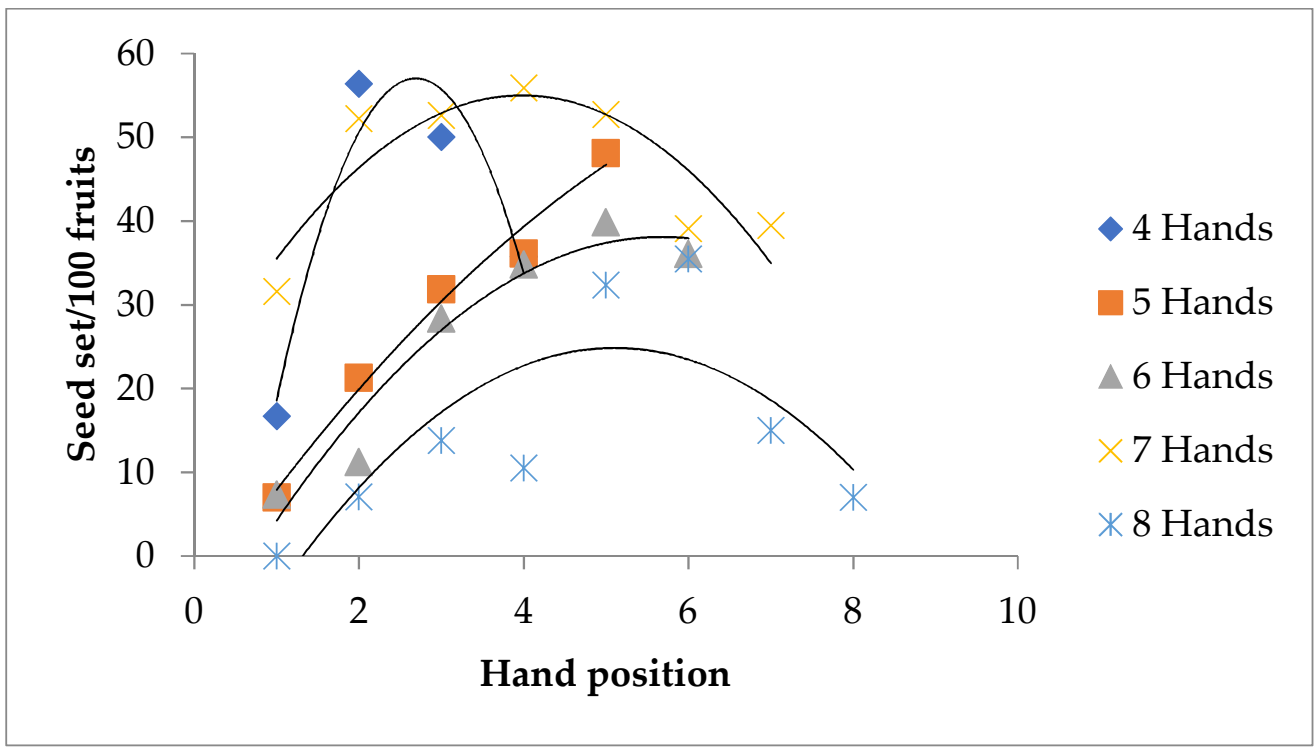

Figure 3. Seed set per 100 fruit per hand in different sized bunches of "Mshale". 


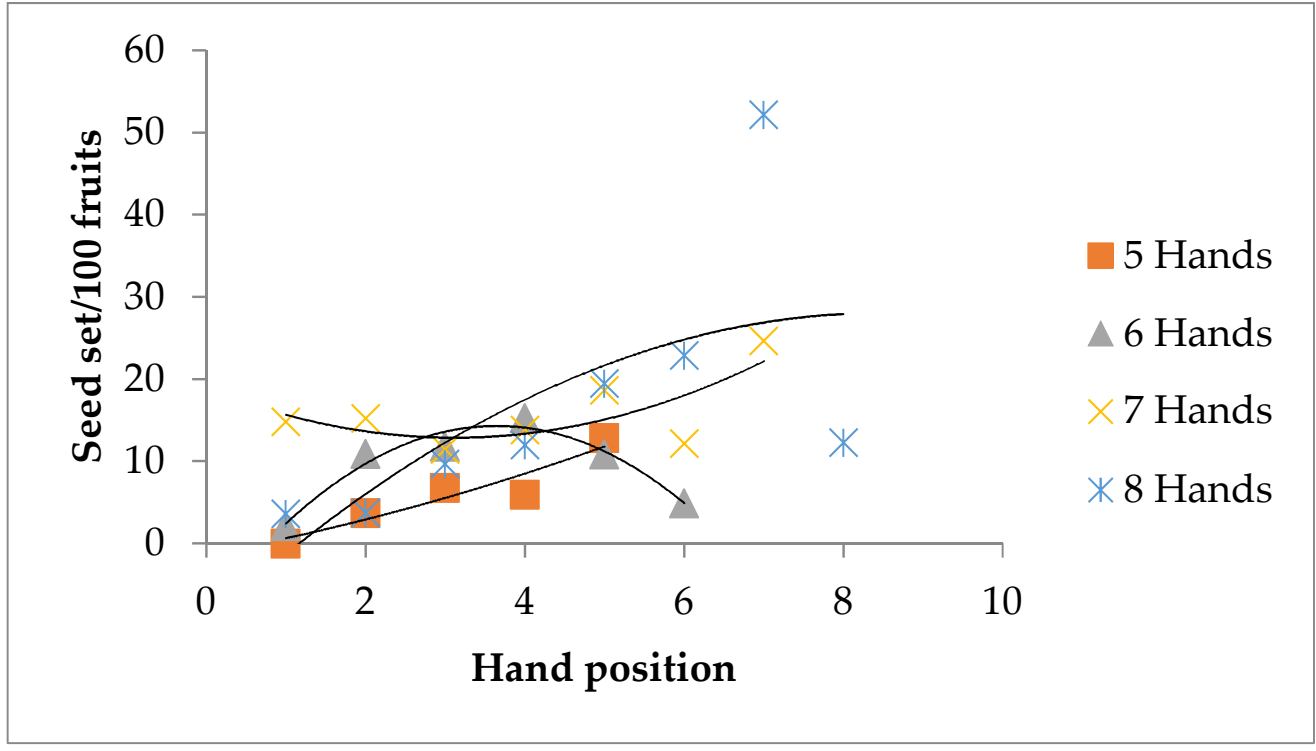

Figure 4. Seed set per 100 fruit per hand in different sized bunches of "Nshonowa".

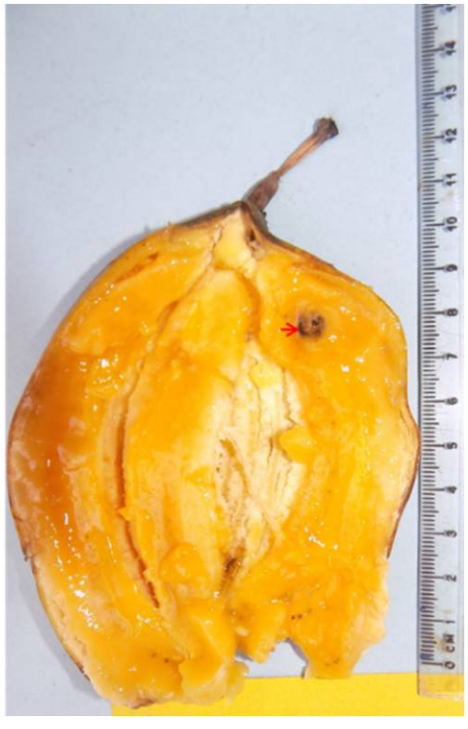

(a)

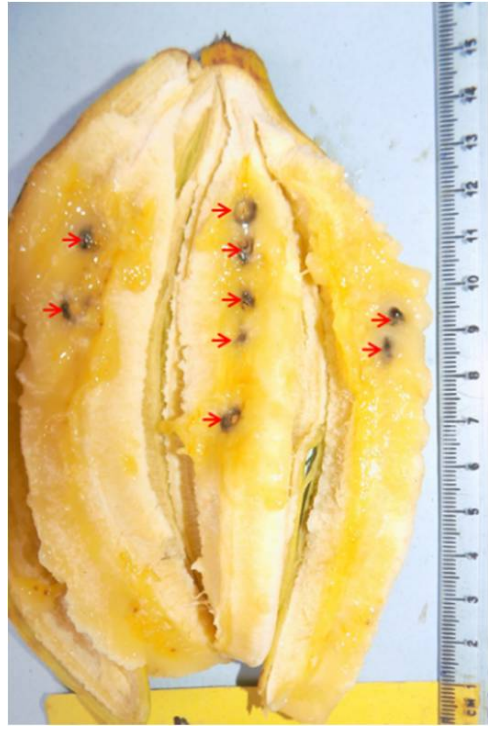

(b)

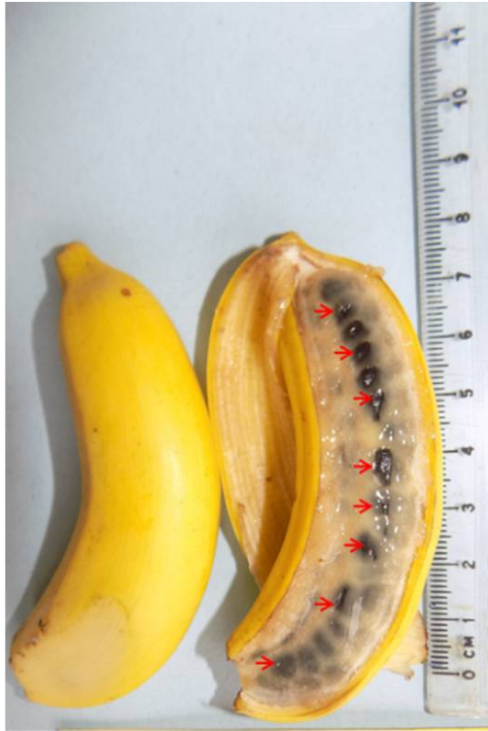

(c)

Figure 5. Seed set position denoted by red arrows in fruits as revealed after ripening among selected banana genotypes. (a) Single seed set in the distal end of "Enzirabahima" pollinated with "Calcutta 4". (b) Multiple seed in the distal end of the fruit in the cultivar "Nshonowa" pollinated with "Calcutta 4". (c) Small intact and peeled fruits of non-parthenocarpic open pollinated wild banana "Calcutta 4" with numerous evenly distributed seed.

Table 3. Second order polynomial and $\mathrm{R}^{2}$ values fitted for seed set per 100 fruits per hand.

\begin{tabular}{ccccccc}
\hline Cultivar & $\begin{array}{c}\text { Bunch Size } \\
\text { (Hands) }\end{array}$ & $\begin{array}{c}\text { Bunch } \\
\text { Number }\end{array}$ & a & b & c & $\mathbf{R}^{\mathbf{2}}$ \\
\hline & 4 & 6 & -2.68 & 18.43 & -15.19 & 0.924 \\
“Enzirabahima” & 5 & 23 & -0.26 & 5.07 & -5.70 & 0.943 \\
(AAA) & 6 & 43 & -0.40 & 5.33 & -4.72 & 0.915 \\
& 7 & 34 & -0.36 & 5.02 & -5.61 & 0.880 \\
& 8 & 7 & -0.25 & 2.65 & -2.21 & 0.447 \\
\hline
\end{tabular}


Table 3. Cont.

\begin{tabular}{ccccccc}
\hline Cultivar & $\begin{array}{c}\text { Bunch Size } \\
\text { (Hands) }\end{array}$ & $\begin{array}{c}\text { Bunch } \\
\text { Number }\end{array}$ & a & b & c & $\mathbf{R}^{\mathbf{2}}$ \\
\hline \multirow{2}{*}{ "Mshale" (AA) } & 4 & 2 & -13.49 & 72.53 & -40.47 & 0.922 \\
& 5 & 31 & -0.77 & 14.34 & -5.64 & 0.982 \\
& 6 & 47 & -1.55 & 17.56 & -11.77 & 0.939 \\
& 7 & 29 & -2.19 & 17.46 & 20.25 & 0.773 \\
& 8 & 4 & -1.73 & 17.66 & -20.21 & 0.629 \\
\hline \multirow{2}{*}{ "Nshonowa" (AA) } & 5 & 10 & 0.17 & 1.78 & -1.33 & 0.886 \\
& 6 & 11 & -1.69 & 12.34 & -8.22 & 0.948 \\
& 7 & 17 & 0.62 & -3.84 & 18.84 & 0.529 \\
& 9 & 14 & -0.52 & 8.86 & -9.63 & 0.447 \\
& 10 & 3 & 0.94 & -7.06 & 15.84 & 0.384 \\
\end{tabular}

\section{Discussion}

Getting an in depth understanding of seed set patterns in EAHBs is certainly one of the measures that will help in designing experiments for increasing seed set in Musa spp. The end goal is to have a fast and an efficient banana breeding pipeline with better hybrids for many farmers in the tropics and subtropical regions globally. Here, there is a deliberate effort to understand the cause of sterility by looking at seed set patterns in relation to position of the hands, bunch size, and position in the fruit in EAHBs. In Musa spp. sterility has been understood to arise from developmental errors in the sporophyte, the gametophyte as well as pistil-pollen interactions. However, more emphasis has been placed on understanding the gametophyte which is said to account most towards sterility [17]. Meiotic errors as a result of chromosome mismatch were reported by Reference [26] to cause embryo sac failure in sterile Musa spp. Reference [27], however, found that about $10 \%$ of embryo sacs in ovules of triploid bananas were correctly positioned compared to $75 \%$ in Musa acuminata ssp. They also discovered that the presence of a B-genome increased the presence of an embryo sac to $96-100 \%$. However, these observations do not explain the fact that seed set in EAHBs is biased toward distal hands and distal end of the fruit. There is also no documentation of a link between the presence and correct positioning of an embryo sac to seasonal influence of seed set in Musa spp. with residual fertility.

Because of the nature of banana, an equal number of bunches could not be obtained for all bunch size categories. For a given genotype, bunch size is dependent on soil and environment [17]. Consequently, the smallest and largest bunch size categories were not well represented thus reliable conclusions cannot be drawn these categories. However, most bunch size categories had a representative number of bunches from which our discussion is based. The observed bias of seed set in distal hands especially in Matooke has been attributed to the high stigma receptivity in distal hands [19]. However, if this were entirely true, then the use of PGM on stigmas would have increased seed set in the proximal hands as well since all hands are pollinated [24]. Additionally, since "Enzirabahima" was reported to have fairly high stigma receptivity in all hands, seed set should have been distributed in all hands. Instead, seed set increase was observed in the same hand positions as of bunches pollinated without PGM. Use of PGM should have also resulted in seed set in "Nakitembe" and "Mlelembo" if stigma receptivity was a prime contributor of sterility in Musa. This implies that there are other factors which come into play after pollen has germinated on the stigmas in different hand positions. The necrosis formed in the prolongation zone of fruits after anthesis especially in triploids [28] could partly account for absence of seed set in proximal hands. This necrosis acts as a barrier to pollen tube growth. Reference [16] observed that pollen tube growth through the stigma in "Gros Michel" looked natural, but was slowed or arrested and the tips developed a swelling resulting in pollen tubes not reaching the ovules. It may be worthwhile to investigate rates of necrosis formation in fruits of different hand positions to find a link to seed set if any. 
In an attempt to avoid the necrosis formed soon after anthesis in the fruit prolongation zone, early pollinations were made (technique three), but the technique did not increase seed set. Reference [29] speculated that physiologically immature stigmas may delay or prevent penetration by pollen tubes and this could have been the case with early pollination. Results in the present study suggest that application of PGM on stigmas enhanced pollen germination [24]. However, this was most effective on stigmas presumed to be physiologically mature after natural flower opening as suggested by Reference [29]. This observation may also suggest that arrest of pollen tube growth may be a biochemical rather than a physical process. It is supported by the fact that a necrosis is not formed in the prolongation fruit zone of diploids [28]. Pollination technique three was therefore discontinued in December 2016 since seed set was lower compared with the customary pollination technique described by Reference [23]. Evening pollinations were also discontinued in 2016 since they did not increase seed set. This resulted from reduced pollen viability with time of the day coupled with low humidity at the time of pollination between 5:00 and 6:30 p.m. The rationale of evening pollination was to have flowers pollinated soon after opening as Musa flowers start opening from evening through the night [30]. However, not all female flowers had fully opened at the time of evening pollination and fresh pollen could not be obtained. Fairly reliable comparisons were made between the control and technique two, since a considerable number of bunches were fairly distributed in different months of year during the study period (Appendix C Tables A5-A7).

Reference [19] found that bracts of distal female hands opened to a bigger angle than that of proximal hands. This phenomenon was linked to a response of stigma receptivity which increased from proximal to distal hands. However, it might be that ovules in proximal hands and the proximal fruit end have higher abortion rates if pollen tubes reach them. Abortive ovules have been reported in other crops, like hazelnut, whereby some unigenes are upregulated and others down regulated in abortive ovules compared to developing ovules [31]. The gradual increase of seed set from proximal to distal hands could suggest a mechanism of ovule abortion rate in the same order. The most likely cause of this observation could be auxins in large amounts from the root tips that reach proximal hands first. Auxins induce formation of edible pulp in both seeded and non-seed bananas as well as partially parthenocarpic types [32,33]. Moreover, in seeded bananas, synthetic auxins 4-CPA and 2,4,5-T have been reported to hinder seed development [33]. Auxins therefore play a critical role in parthenocarpy, as well as sterility.

The effect of weather on seed set in Musa spp. could be as a result of a drop in auxin levels with heat and/or moisture stress. This comes with high temperature, high solar radiation, and low rainfall. These weather conditions correlate with increase in seed set in Matooke [21]. This is likely to slow down evapo-transpiration pull as the plant tries to conserve moisture. Consequently, materials moving from roots including auxins do not reach the distal hands and fruit tips in adequate amounts. A reduced fruit circumference of "Gros Michel" correlates with increased seed set [18], which can reflect reduced parthenocarpy. This theory also tends to fit the observed increase of seed set per 100 fruits with increase in bunch size; small bunches are saturated easily. A reduction in auxin levels during moisture stress could be caused by salicylic acid which is involved in response to both abiotic and biotic stress [34,35]. Salicylic acid and auxin signaling are mutually antagonist [35] and production of salicylic acid in response to moisture stress or heat stress could be responsible for reduced auxin levels thus reduced parthenocarpy. This may be linked to the sudden seed set increase observed in bunches from mats on pockets of soils which drain easily. This results in high salicylic acid production in response to moisture stress and consequently high seed set.

There were inconsistences in patterns of seed set in "Nshonowa" as fewer bunches were available compared with the other two cultivars. Using few bunches with seed to calculate averages for "Nshonowa" implied that a single bunch with high seed set affected the overall shape of the curve. It was also noticed that bunches with high seed set had uneven seed distribution among hands. Sudden seed increase was observed in hand 
position seven of the eight-hand-bunch category. It strongly suggests that there are specific weather conditions for maximum seed set, as hands were pollinated on different days with unique weather conditions. High morning temperatures are likely to overcome the issue of pollen tube growth arrest. In citrus [36] and in apples [37], high temperature was reported to overcome self-incompatibility; it could be a similar issue in banana, as high temperature is associated with high seed set [21]. This could have applied to all the three EAHBs, but use of many bunches evened out this effect in "Enzirabahima" and "Mshale", since more bunches had seed.

Results in the current study revealed that the hands with the highest number of fruits do not necessary produce the highest number of seeds. This clearly suggests that there are other factors that are more important for seed set. Ideally, it is expected that different sized bunches have same pollination success and same seed set per 100 fruits. However, our observations suggest that bunch size has an influence on fertility based on differences of seed set per 100 fruits for different bunch sizes. Reference [18] also observed an increase of seed set on 100 fruit basis from small to larger bunches of "Gros Michel" as observed in EAHBs. The current study also revealed that big bunches are more fertile than smaller bunches in terms pollination success. The theory of auxins influencing fertility in different bunch sizes seems to fit this observation. Smaller bunches would be easily saturated by auxins compared with larger bunches. This leads to the low seed set (per 100 fruit basis) and low pollination success in smaller compared to larger bunches. However, there is higher seed set per 100 fruit per hand in smaller bunches if only bunches with seed are considered. However, large bunches generally set more seed per hand as a result of higher pollination success compared to small bunches.

All of these observations call for a slightly different approach to better understand sterility and use it profitably as it is a prerequisite in the final hybrids. It may be the right time for banana researchers to start looking in the direction of hormonal manipulations for increased seed set. However, since segregation data suggest that parthenocarpy and sterility are independent [26], this would rule out auxins as the sole cause of sterility in Musa spp. A recent genome wide association study in Musa found parthenocarpy genes to be potentially linked to seedlessness. However, the prime candidate gene was the gene orthologous to Histadine Kinase CKI1 [38]. Cytokinins have been reported to determine the fate of seed development [39] and they could be responsible for sterility in Musa even if there is successful fertilization. Non-parthenocarpic progeny that has sterile plants could therefore point to ovule abortion. This stems from a mutation in the gene orthologous to Histadine Kinase CKI1 that was linked to seedlessness by Reference [38].

It could be possible that the same gene orthologous to Histadine Kinase CKI1 is responsible for production of poor seed and low embryo rescue rates in some parental combinations. Some edible banana genotypes have been rendered "infertile" and this could be as a result of hyper production auxin individually or in combination with the gene orthologous to Histadine Kinase CKI1 which has been linked to seedlessness. It could be that relative contribution these two factors along with other factors that result in high sterility as observed in "Nakitembe" and "Mlelembo". Other factors such as fruit length are involved in banana fertility as demonstrated in the current study. In "Calcutta 4 ", seeds set covers the entire length of the fruit implying pollen tube growth covered an estimated distance of $10 \mathrm{~cm}$. In "Nshonowa", pollen tube growth covered about $10 \mathrm{~cm}$ and about $7 \mathrm{~cm}$ of the fruit pulp had no seed. Moreover, in "Enzirabahima", pollen tubes cover a distance of about $5 \mathrm{~cm}$ with about $8 \mathrm{~cm}$ of pulp without seed. This suggests that pollen tube growth within the fruit is not the reason for a biased seed set towards the fruit tip as the distance covered in "Enzirabahima" is shorter. With the same approach of auxin involvement in Musa fertility, it likely that auxins can cover a limited distance during moisture stress thus longer fingers set more seed. This explains the higher seed set observed in Mchare compared with Matooke in the current study. The drop in seed set from the last hand could also be as a result of reduced fruit length in the last hand. Fruits in the proximal hands are longer with bigger circumference which reduces towards the 
distal end of the bunch. This was reported in plantain and cooking-banana types: Distal hands have fruits with the least fruit length [40].

\section{Conclusions}

The results of this study demonstrated that small sized bunches of EAHBs have low seed set and pollination success rates. Seed set in EAHBs is mainly predominant in the distal hands starting in the mid-section of the bunch. Seed set in fruits is also skewed to the distal end with evidence that fruit length and bunch maturity period being involved in fertility. The study also showed that seed set patterns in hand positions are not influenced by stigma receptivity as earlier thought. There is a mechanism that prevents seed set in proximal hands that needs further experimentation to be understood. Auxins are likely to be one of the most important causes of sterility in Musa, but they are not entirely responsible. A holistic approach will therefore be required to increase seed set and overcome sterility. Efforts have to be devoted to improving in vivo pollen germination and having agronomic practices that increase bunch size. In the future, scientists may have to consider hormonal manipulations especially those that will reduce parthenocarpy. Overcoming sterility will ultimately broaden the parental base to include genotypes whose breeding potential is unknown. A selection criterion of parents has always included male and female fertility trait, yet such parents are often non-parthenocarpic. Being able to use parents with parthenocarpy and inherent sterility in crosses will increase the number of parthenocarpic hybrids per cross and, thus, ensure a more efficient breeding pipeline.

Author Contributions: Conceptualization, A.W., R.S. and A.K.T.; methodology, A.W.; software, A.W.; validation, A.W., R.S., S.B.M., A.K.T. and R.T.; formal analysis, A.W.; investigation, A.W.; resources, J.K., W.K.T. and R.T.; data curation, A.W.; writing-original draft preparation, A.W.; writing-review and editing, all authors; visualization, A.W., R.S., S.B.M. and A.K.T.; supervision, A.W.; project administration, R.S., J.K., W.K.T. and R.T.; funding acquisition, R.S., J.K., W.K.T. and R.T. All authors read and agreed to the published version of the manuscript.

Funding: This research was funded by the Bill \& Melinda Gates Foundation, opportunity ID OPP1093845 and the APC was also funded by the Bill \& Melinda Gates Foundation.

Institutional Review Board Statement: Not applicable.

Informed Consent Statement: Not applicable.

Data Availability Statement: All data is presented.

Acknowledgments: Ongoing studies on increasing seed set in banana (Matooke and Mchare) are part of the PhD study of the first author. We recognize Breeding Better Banana project which funded the studies on banana floral biology. The authors also thank all donors who supported this work through their contributions to the CGIAR Fund (http:/ / www.cgiar.org/funders / accessed on 14 August 2020), and in particular to the CGIAR Research Program for Roots, Tubers and Bananas (CRP-RTB). We further acknowledge editing advice offered by Jim Lorenzen, Bill \& Melinda Gates Foundation, Seattle, Washington; and Jane Gibbs and David W. Turner, School of Agriculture and Environment, Faculty of Science, The University of Western Australia.

Conflicts of Interest: The authors declare no competing interest. 


\section{Appendix A}

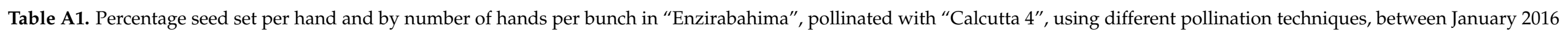
and January 2019.

\begin{tabular}{|c|c|c|c|c|c|c|c|c|c|c|c|c|c|c|c|}
\hline $\begin{array}{l}\text { Total Bunch } \\
\text { Number }\end{array}$ & $\begin{array}{l}\text { Bunch Size } \\
\text { (Hands) }\end{array}$ & Pol Tech & $\begin{array}{l}\text { Bunches } \\
\text { with Seed }\end{array}$ & $\begin{array}{l}\text { Success } \\
\text { Rate (\%) }\end{array}$ & $\begin{array}{c}\text { Seed Set } \\
\text { Range }\end{array}$ & $\begin{array}{c}\text { Average Seed Set } \\
(/ 100 \mathrm{fr})\end{array}$ & 1 & 2 & 3 & 4 & 5 & 6 & 7 & 8 & 9 \\
\hline 21 & 4 & 1 & 2 & 9.5 & $0-4$ & 0.66 & 0.0 & 33.3 & 50.0 & 16.7 & & & & & \\
\hline 13 & 4 & 2 & 3 & 23.1 & $0-13$ & 2.91 & 5.0 & 20.0 & 40.0 & 35.0 & & & & & \\
\hline 9 & 4 & 4 & 0 & 0.0 & $0-0$ & 0.00 & 0.0 & 0.0 & 0.0 & 0.0 & & & & & \\
\hline 63 & 5 & 1 & 13 & 20.6 & $0-12$ & 1.55 & 0.0 & 2.5 & 25.0 & 42.5 & 30.0 & & & & \\
\hline 57 & 5 & 2 & 16 & 28.1 & $0-7$ & 1.54 & 0.0 & 6.1 & 32.7 & 26.5 & 34.7 & & & & \\
\hline 13 & 5 & 3 & 0 & 0.0 & $0-0$ & 0.00 & 0.0 & 0.0 & 0.0 & 0.0 & 0.0 & & & & \\
\hline 37 & 6 & 1 & 10 & 27.0 & $0-6$ & 1.07 & 3.3 & 3.3 & 10.0 & 26.7 & 50.0 & 6.7 & & & \\
\hline 64 & 6 & 2 & 13 & 43.8 & $0-33$ & 4.06 & 1.5 & 12.7 & 15.2 & 29.9 & 19.3 & 21.3 & & & \\
\hline 21 & 6 & 3 & 7 & 28.6 & $0-3$ & 0.70 & 0.0 & 0.0 & 22.2 & 44.4 & 11.1 & 22.2 & & & \\
\hline 7 & 6 & 4 & 2 & 28.6 & $0-3$ & 0.80 & 0.0 & 0.0 & 0.0 & 50.0 & 25.0 & 25.0 & & & \\
\hline 27 & 7 & 1 & 14 & 51.9 & $0-15$ & 3.87 & 0.0 & 7.1 & 22.4 & 6.1 & 20.4 & 27.6 & 16.3 & & \\
\hline 31 & 7 & 2 & 18 & 58.1 & $0-16$ & 2.82 & 0.0 & 5.4 & 8.1 & 21.6 & 18.9 & 33.8 & 12.2 & & \\
\hline 15 & 7 & 3 & 6 & 40.0 & $0-27$ & 3.24 & 0.0 & 0.0 & 10.5 & 23.7 & 52.6 & 13.2 & $\begin{array}{c}12.2 \\
0.0\end{array}$ & & \\
\hline 2 & 7 & 4 & 0 & 0.0 & $0-0$ & 0.00 & 0.0 & 0.0 & 0.0 & 0.0 & 0.0 & 0.0 & 0.0 & & \\
\hline 7 & 8 & 1 & 3 & 42.9 & $0-21$ & 3.04 & 0.0 & 0.0 & 0.0 & 0.0 & 0.0 & 60.0 & 40.0 & 0.0 & \\
\hline 6 & 8 & 3 & 6 & 100.0 & $1-13$ & 3.96 & 0.0 & 0.0 & 25.0 & 41.7 & 16.7 & 0.0 & 8.3 & 8.3 & \\
\hline 1 & 8 & 4 & 0 & 0.0 & $0-0$ & 0.00 & 0.0 & 0.0 & 0.0 & 0.0 & 0.0 & 0.0 & 0.0 & 0.0 & \\
\hline 1 & 9 & 1 & 0 & 0.0 & $0-0$ & 0.00 & 0.0 & 0.0 & 0.0 & 0.0 & 0.0 & 0.0 & 0.0 & 0.0 & 0.0 \\
\hline
\end{tabular}

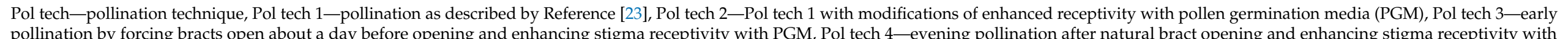
PGM, fr-fruits. 


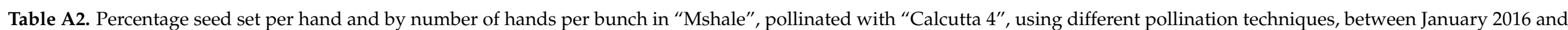
January 2019.

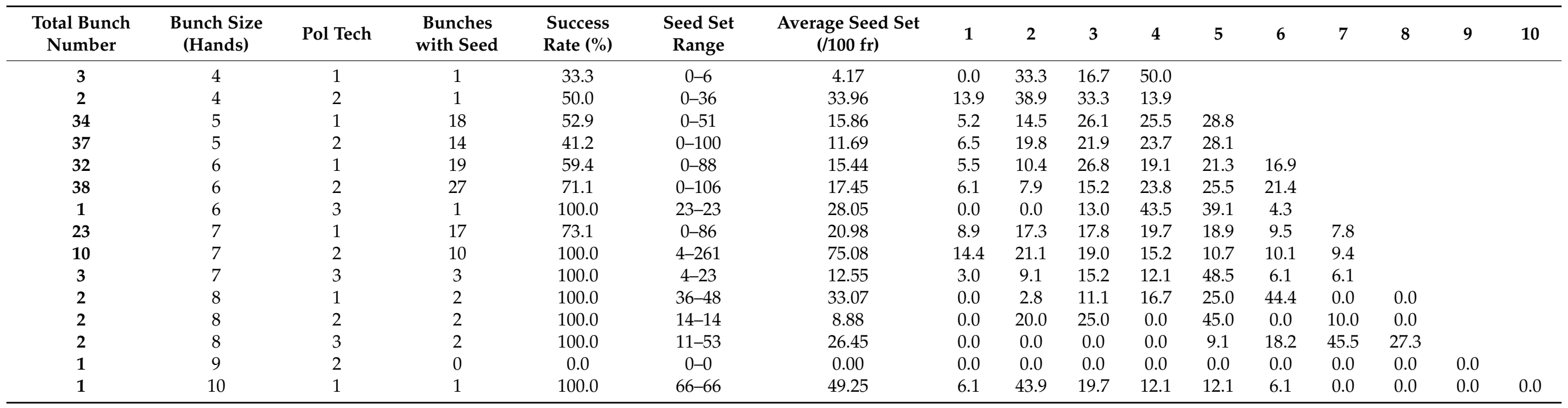

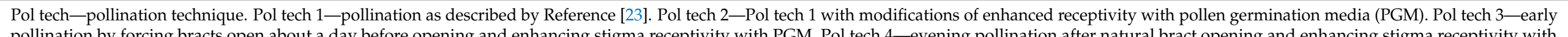
PGM. Fr-fruits.

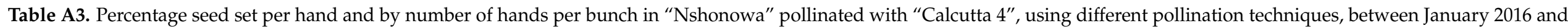
January 2019.

\begin{tabular}{|c|c|c|c|c|c|c|c|c|c|c|c|c|c|c|c|c|}
\hline $\begin{array}{l}\text { Total Bunch } \\
\text { Number }\end{array}$ & $\begin{array}{l}\text { Bunch Size } \\
\text { (Hands) }\end{array}$ & Pol Tech & $\begin{array}{l}\text { Bunches } \\
\text { with Seed }\end{array}$ & $\begin{array}{l}\text { Success } \\
\text { Rate }\end{array}$ & $\begin{array}{l}\text { Seed Set } \\
\text { Range }\end{array}$ & $\begin{array}{l}\text { Average Seed Set } \\
\text { (/100 fr) }\end{array}$ & 1 & 2 & 3 & 4 & 5 & 6 & 7 & 8 & 9 & 10 \\
\hline 5 & 4 & 1 & 0 & 0.0 & $0-0$ & 0.00 & 0.0 & 0.0 & 0.0 & 0.0 & & & & & & \\
\hline 4 & 4 & 2 & 1 & 25.0 & $0-2$ & 0.70 & 0.0 & 0.0 & 0.0 & 100.0 & & & & & & \\
\hline 28 & 5 & 2 & 4 & 14.3 & $0-9$ & 0.97 & 0.0 & 5.0 & 25.0 & 30.0 & 40.0 & & & & & \\
\hline 1 & 5 & 4 & 1 & 100.0 & $4-4$ & 7.84 & 0.0 & 75.0 & 25.0 & 0.0 & 0.0 & & & & & \\
\hline 19 & 6 & 1 & 5 & 26.3 & $0-9$ & 1.59 & 20.0 & 15.0 & 0.0 & 20.0 & 25.0 & 20.0 & & & & \\
\hline 30 & 6 & 2 & 4 & 23.3 & $0-54$ & 2.70 & 0.0 & 24.3 & 28.6 & 28.6 & 15.7 & 2.9 & & & & \\
\hline
\end{tabular}


Table A3. Cont.

\begin{tabular}{|c|c|c|c|c|c|c|c|c|c|c|c|c|c|c|c|c|}
\hline $\begin{array}{l}\text { Total Bunch } \\
\text { Number }\end{array}$ & $\begin{array}{l}\text { Bunch Size } \\
\text { (Hands) }\end{array}$ & Pol Tech & $\begin{array}{l}\text { Bunches } \\
\text { with Seed }\end{array}$ & $\begin{array}{l}\text { Success } \\
\text { Rate }\end{array}$ & $\begin{array}{l}\text { Seed Set } \\
\text { Range }\end{array}$ & $\begin{array}{l}\text { Average Seed Set } \\
(/ 100 \mathrm{fr})\end{array}$ & 1 & 2 & 3 & 4 & 5 & 6 & 7 & 8 & 9 & 10 \\
\hline 1 & 6 & 3 & 0 & 0.0 & $0-0$ & 0.00 & 0.0 & 0.0 & 0.0 & 0.0 & 0.0 & 0.0 & & & & \\
\hline 20 & 7 & 1 & 9 & 45.0 & $0-60$ & 5.47 & 14.8 & 9.9 & 19.8 & 7.4 & 17.3 & 16.0 & 14.8 & & & \\
\hline 4 & 7 & 3 & 1 & 25.0 & $0-3$ & 0.95 & 0.0 & 0.0 & 0.0 & 100.0 & 0.0 & 0.0 & 0.0 & & & \\
\hline 9 & 8 & 1 & 6 & 66.7 & 0-11 & 3.32 & 0.0 & 0.0 & 8.3 & 0.0 & 29.2 & 4.2 & 25.0 & 33.3 & & \\
\hline 14 & 8 & 2 & 10 & 71.3 & $0-85$ & 15.10 & 4.0 & 2.5 & 9.6 & 7.6 & 15.7 & 17.7 & 38.9 & 4.0 & & \\
\hline 4 & 9 & 1 & 3 & 75.0 & $0-4$ & 1.15 & 0.0 & 0.0 & 0.0 & 0.0 & 100.0 & 0.0 & 0.0 & 0.0 & 0.0 & \\
\hline 2 & 9 & 3 & 1 & 50.0 & $0-1$ & 0.50 & 0.0 & 0.0 & 0.0 & 0.0 & 0.0 & 0.0 & 0.0 & 100.0 & 0.0 & \\
\hline 3 & 10 & 2 & 3 & 100.0 & $8-17$ & 7.61 & 3.8 & 11.5 & 0.0 & 0.0 & 19.2 & 19.2 & 26.9 & 0.0 & 0.0 & 19.2 \\
\hline
\end{tabular}

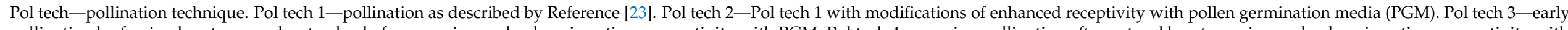

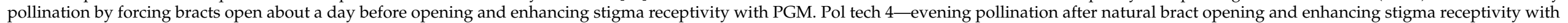

PGM. Fr-fruits.

\section{Appendix B}

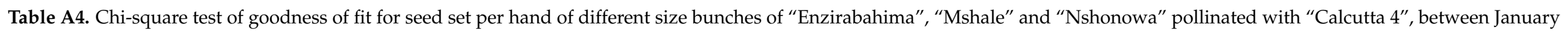
2016 and January 2019.

\begin{tabular}{|c|c|c|c|c|c|c|c|c|c|c|c|}
\hline \multicolumn{4}{|c|}{ Enzirabahima (AAA) } & \multicolumn{4}{|c|}{ Mshale (AA) } & \multicolumn{4}{|c|}{ Nshonowa (AA) } \\
\hline Bunch Size (Hands) & No. of Bunches & $X^{2}{ }_{c a l}$ & $X^{2}$ prob & Bunch Size (Hands) & No. of Bunches & $\mathrm{X}^{2}{ }_{\mathrm{cal}}$ & $\mathrm{X}^{2}$ prob & Bunch Size (Hands) & No. of Bunches & $X^{2}$ cal & $X^{2}$ prob \\
\hline 4 & 6 & 11.18 & 0.011 & 4 & 2 & 6.83 & 0.077 & 4 & 1 & 8.13 & 0.043 \\
\hline 5 & 23 & 62.76 & $<0.001$ & 5 & 31 & 153.67 & $<0.001$ & 5 & 10 & 22.66 & $<0.001$ \\
\hline 7 & 34 & 106.51 & $<0.001$ & 7 & 29 & 42.78 & $<0.001$ & 7 & 17 & 14.61 & 0.024 \\
\hline \multirow[t]{3}{*}{8} & 7 & 14.20 & 0.048 & 8 & 4 & 43.61 & $<0.001$ & 8 & 14 & 191.34 & $<0.001$ \\
\hline & & & & 10 & 1 & 63.92 & $<0.001$ & 9 & 3 & 60.29 & $<0.001$ \\
\hline & & & & & & & & 10 & 3 & 22.40 & 0.008 \\
\hline
\end{tabular}

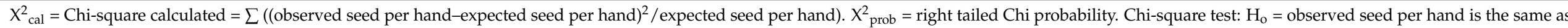

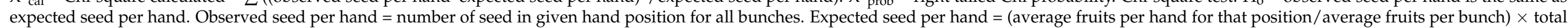
seed. Degrees of freedom = number of hands in bunch size category minus one. No. of bunches = number of bunches with seed used for Chi-square calculations. 


\section{Appendix C}

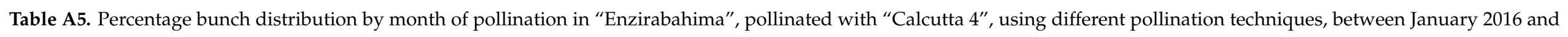
January 2019.

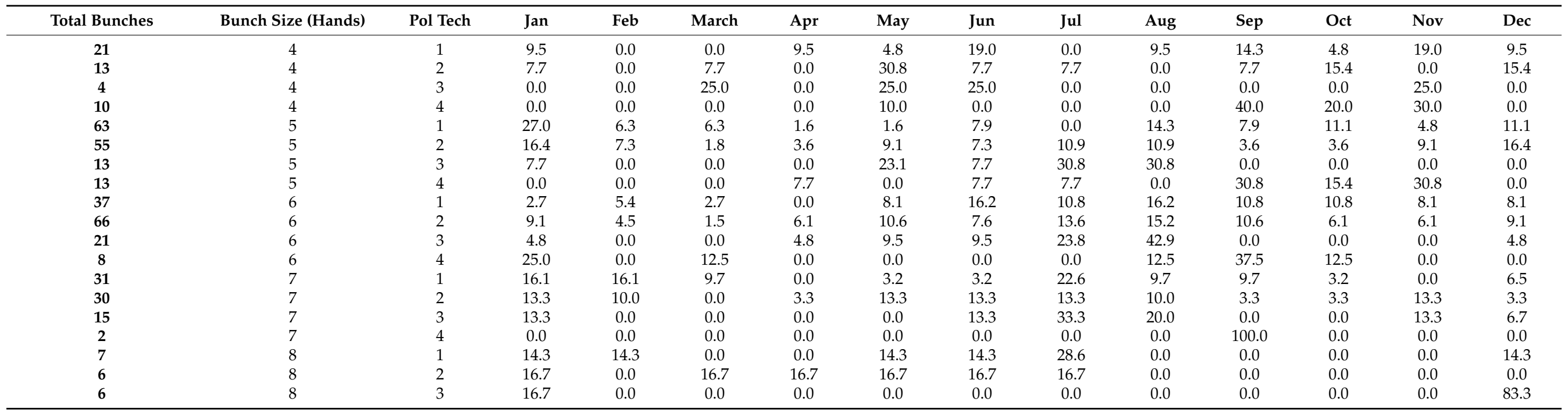

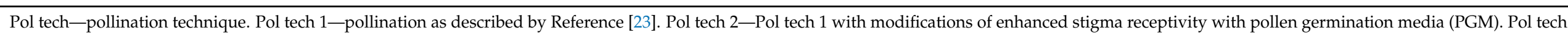

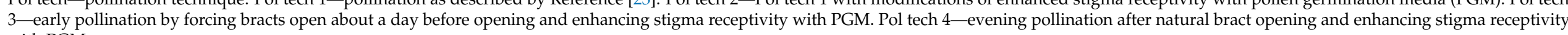
with PGM.

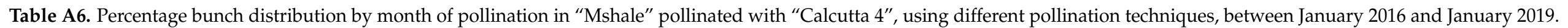

\begin{tabular}{|c|c|c|c|c|c|c|c|c|c|c|c|c|c|c|}
\hline Total Bunches & Bunch Size (Hands) & Pol Tech & Jan & Feb & March & Apr & May & Jun & Jul & Aug & Sep & Oct & Nov & Dec \\
\hline 3 & 4 & 1 & 0.0 & 0.0 & 0.0 & 0.0 & 0.0 & 0.0 & 0.0 & 0.0 & 33.3 & 0.0 & 33.3 & 33.3 \\
\hline 2 & 4 & 2 & 0.0 & 0.0 & 0.0 & 0.0 & 0.0 & 0.0 & 0.0 & 0.0 & 50.0 & 0.0 & 50.0 & 0.0 \\
\hline 34 & 5 & 1 & 14.7 & 0.0 & 0.0 & 0.0 & 2.9 & 2.9 & 14.7 & 14.7 & 11.8 & 11.8 & 20.6 & 5.9 \\
\hline 37 & 5 & 2 & 21.6 & 0.0 & 0.0 & 0.0 & 5.4 & 8.1 & 8.1 & 18.9 & 10.8 & 8.1 & 10.8 & 8.1 \\
\hline 38 & 6 & 2 & 2.6 & 2.6 & 2.6 & 0.0 & 18.4 & 13.2 & 15.8 & 10.5 & 7.9 & 7.9 & 10.5 & 7.9 \\
\hline 1 & 6 & 3 & 0.0 & 0.0 & 0.0 & 0.0 & 0.0 & 0.0 & 0.0 & 0.0 & 0.0 & 0.0 & 0.0 & 100.0 \\
\hline
\end{tabular}


Table A6. Cont.

\begin{tabular}{|c|c|c|c|c|c|c|c|c|c|c|c|c|c|c|}
\hline Total Bunches & Bunch Size (Hands) & Pol Tech & Jan & Feb & March & Apr & May & Jun & Jul & Aug & Sep & Oct & Nov & Dec \\
\hline 20 & 7 & 1 & 0.0 & 10.0 & 15.0 & 10.0 & 10.0 & 5.0 & 15.0 & 15.0 & 0.0 & 5.0 & 5.0 & 10.0 \\
\hline 9 & 7 & 2 & 22.2 & 11.1 & 0.0 & 22.2 & 0.0 & 0.0 & 0.0 & 33.3 & 11.1 & 0.0 & 0.0 & 0.0 \\
\hline 3 & 7 & 3 & 66.7 & 33.3 & 0.0 & 0.0 & 0.0 & 0.0 & 0.0 & 0.0 & 0.0 & 0.0 & 0.0 & 0.0 \\
\hline 2 & 8 & 1 & 0.0 & 100.0 & 0.0 & 0.0 & 0.0 & 0.0 & 0.0 & 0.0 & 0.0 & 0.0 & 0.0 & 0.0 \\
\hline 2 & 8 & 2 & 0.0 & 0.0 & 50.0 & 0.0 & 0.0 & 0.0 & 0.0 & 0.0 & 0.0 & 0.0 & 50.0 & 0.0 \\
\hline 1 & 8 & 3 & 0.0 & 0.0 & 0.0 & 0.0 & 0.0 & 0.0 & 0.0 & 0.0 & 0.0 & 0.0 & 0.0 & 100.0 \\
\hline 1 & 9 & 2 & 0.0 & 0.0 & 0.0 & 0.0 & 0.0 & 0.0 & 0.0 & 0.0 & 0.0 & 0.0 & 0.0 & 100.0 \\
\hline 1 & 10 & 1 & 100.0 & 0.0 & 0.0 & 0.0 & 0.0 & 0.0 & 0.0 & 0.0 & 0.0 & 0.0 & 0.0 & 0.0 \\
\hline
\end{tabular}

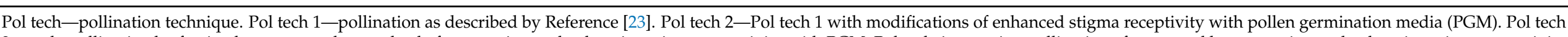

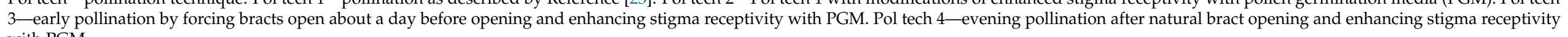
with PGM.

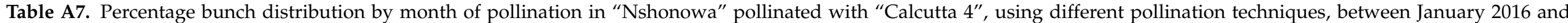
January 2019.

\begin{tabular}{|c|c|c|c|c|c|c|c|c|c|c|c|c|c|c|}
\hline Total Bunches & Bunch Size (Hands) & Pol Tech & Jan & Feb & March & Apr & May & Jun & Jul & Aug & Sep & Oct & Nov & Dec \\
\hline 5 & 4 & 1 & 20.0 & 0.0 & 0.0 & 0.0 & 0.0 & 0.0 & 0.0 & 20.0 & 20.0 & 20.0 & 20.0 & 0.0 \\
\hline 4 & 4 & 2 & 25.0 & 0.0 & 0.0 & 0.0 & 0.0 & 25.0 & 0.0 & 0.0 & 25.0 & 25.0 & 0.0 & 0.0 \\
\hline 1 & 4 & 3 & 0.0 & 0.0 & 0.0 & 0.0 & 0.0 & 0.0 & 0.0 & 0.0 & 0.0 & 0.0 & 0.0 & 100.0 \\
\hline 28 & 5 & 1 & 7.1 & 0.0 & 3.6 & 0.0 & 7.1 & 0.0 & 14.3 & 7.1 & 17.9 & 14.3 & 21.4 & 7.1 \\
\hline 4 & 5 & 3 & 25.0 & 0.0 & 0.0 & 0.0 & 0.0 & 50.0 & 0.0 & 0.0 & 0.0 & 0.0 & 0.0 & 25.0 \\
\hline 19 & 6 & 1 & 10.5 & 5.3 & 0.0 & 10.5 & 0.0 & 10.5 & 5.3 & 15.8 & 10.5 & 5.3 & 10.5 & 15.8 \\
\hline 30 & 6 & 2 & 10.0 & 3.3 & 3.3 & 6.7 & 6.7 & 20.0 & 6.7 & 6.7 & 6.7 & 3.3 & 10.0 & 16.7 \\
\hline 1 & 6 & 3 & 0.0 & 100.0 & 0.0 & 0.0 & 0.0 & 0.0 & 0.0 & 0.0 & 0.0 & 0.0 & 0.0 & 0.0 \\
\hline 20 & 7 & 1 & 5.0 & 15.0 & 5.0 & 20.0 & 20.0 & 5.0 & 0.0 & 10.0 & 0.0 & 5.0 & 0.0 & 15.0 \\
\hline 4 & 7 & 3 & 0.0 & 0.0 & 25.0 & 50.0 & 0.0 & 0.0 & 25.0 & 0.0 & 0.0 & 0.0 & 0.0 & 0.0 \\
\hline 9 & 8 & 1 & 55.6 & 11.1 & 0.0 & 0.0 & 11.1 & 0.0 & 0.0 & 11.1 & 0.0 & 0.0 & 0.0 & 11.1 \\
\hline 13 & 8 & 2 & 15.4 & 7.7 & 23.1 & 7.7 & 15.4 & 0.0 & 7.7 & 7.7 & 0.0 & 7.7 & 0.0 & 7.7 \\
\hline 7 & 8 & 3 & 14.3 & 0.0 & 0.0 & 14.3 & 0.0 & 0.0 & 0.0 & 0.0 & 0.0 & 0.0 & 0.0 & 71.4 \\
\hline 4 & 9 & 1 & 0.0 & 0.0 & 25.0 & 0.0 & 0.0 & 0.0 & 0.0 & 0.0 & 0.0 & 0.0 & 0.0 & 75.0 \\
\hline 6 & 9 & 2 & 33.3 & 0.0 & 16.7 & 0.0 & 16.7 & 0.0 & 0.0 & 0.0 & 0.0 & 0.0 & 0.0 & 33.3 \\
\hline 2 & 9 & 3 & 0.0 & 0.0 & 0.0 & 0.0 & 0.0 & 0.0 & 0.0 & 0.0 & 0.0 & 0.0 & 0.0 & 100.0 \\
\hline 2 & 10 & 2 & 0.0 & 0.0 & 50.0 & 0.0 & 0.0 & 0.0 & 0.0 & 50.0 & 0.0 & 0.0 & 0.0 & 0.0 \\
\hline 1 & 11 & 1 & 0.0 & 0.0 & 0.0 & 0.0 & 0.0 & 0.0 & 0.0 & 0.0 & 0.0 & 0.0 & 0.0 & 100.0 \\
\hline
\end{tabular}

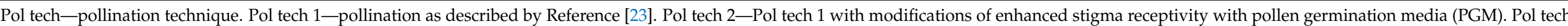

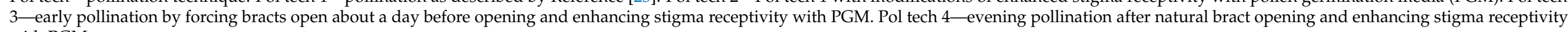




\section{References}

1. NBSP. Faostat Production-Crops. Available online: http://www.fao.org/faostat/en/\#compare (accessed on 11 March 2019).

2. Robinson, J.C.; Saúco, V.G. Bananas and Plantains, 2nd ed.; CABI: Oxfordshire, UK, 2010. [CrossRef]

3. FAO. Banana Market Review 2019; FAO: Rome, Italy, 2020.

4. Karamura, D.A.; Karamura, E.; Tinzaara, W. Banana Cultivar Names, Synonyms and Their Usage in Eastern Africa, Bioversity International, Uganda; Bioversity International: Rome, Italy, 2012.

5. Pillay, M.; Ssebuliba, R.; Hartman, J.; Vuylsteke, D.; Talengera, D.; Tushemereirwe, W. Conventional breeding strategies to enhance the sustainability of Musa biodiversity conservation for endemic cultivars. Afr. Crop Sci. J. 2004, 12, 58-65. [CrossRef]

6. $\quad$ Pillay, M.; Tripathi, L. Banana Breeding; Wiley: Hoboken, NJ, USA, 2008; pp. 393-428.

7. Němečková, A.; Christelová, P.; Čížková, J.; Nyine, M.; Houwe, I.V.D.; Svačina, R.; Uwimana, B.; Swennen, R.; Doležel, J.; Hřibová, E. Molecular and Cytogenetic Study of East African Highland Banana. Front. Plant Sci. 2018, 9, 1371. [CrossRef]

8. Raboin, L.-M.; Carreel, F.; Noyer, J.-L.; Baurens, F.-C.; Horry, J.-P.; Bakry, F.; Du Montcel, H.T.; Ganry, J.; Lanaud, C.; Lagoda, P.J.L. Diploid Ancestors of Triploid Export Banana Cultivars: Molecular Identification of 2n Restitution Gamete Donors and $\mathrm{n}$ Gamete Donors. Mol. Breed. 2005, 16, 333-341. [CrossRef]

9. De Langhe, E.; Karamura, D.; Mbwana, A. Tanzania Musa Expedition 2001; INIBAP: Kampala, Uganda, 2001.

10. Perrier, X.; Jenny, C.; Bakry, F.; Karamura, D.; Kitavi, M.; Dubois, C.; Hervouet, C.; Philippson, G.; De Langhe, E. East African diploid and triploid bananas: A genetic complex transported from South-East Asia. Ann. Bot. 2018, 123, 19-36. [CrossRef] [PubMed]

11. Viljoen, A.; Mahuku, G.; Massawe, C.; Ssali, R.T.; Kimunye, J.; Mostert, G.; Ndayihanzamaso, P.; Coyne, D.L. Banana Diseases and Pests: Field Guide for Diagnostics and Data Collection; IITA: Ibadan, Nigeria, 2017.

12. Ortiz, R.; Swennen, R. From crossbreeding to biotechnology-facilitated improvement of banana and plantain. Biotechnol. Adv. 2014, 32, 158-169. [CrossRef] [PubMed]

13. Ssebuliba, R.N.; Rubaihayo, P.; Tenkouano, A.; Makumbi, D.; Talengera, D.; Magambo, M. Genetic diversity among East African Highland Bananas for female fertility. Afr. Crop Sci. J. 2005, 13, 13-26.

14. Ssebuliba, R.; Talengera, D.; Makumbi, D.; Namanya, P.; Tenkouano, A.; Tushemereirwe, W.; Pillay, M. Reproductive efficiency and breeding potential of East African highland (Musa AAA-EA) bananas. Field Crops Res. 2006, 95, 250-255. [CrossRef]

15. Ray, P.K. Breeding Tropical and Subtropical Fruits; Norosa Publishing House: Pusa, India, 2002.

16. Shepherd, K. Seed fertility of 'Gros Michel' bananas. Trop. Agric. Trinidad 1960, 37, 211-221. [CrossRef]

17. Fortescue, J.A.; Turner, D.W. Reproductive Biology. In Banana Breeding: Progress and Challenges; Pillay, M., Tenkouano, A., Eds.; CRC Press: Boca Raton, EL, USA; London, UK; New York, NY, USA, 2011; pp. 145-179. [CrossRef]

18. Shepherd, K. Seed Fertility of the Gros Michel Banana in Jamaica. J. Hortic. Sci. 1954, 29, 1-11. [CrossRef]

19. Ssebuliba, R.; Magambo, M.; Talengera, D.; Makumbi, D.; Tenkouano, A.; Rubaihayo, P.; Pillay, M. Biological Factors Affecting Seed Production in East African Highland Bananas. J. Crop Improv. 2006, 16, 67-79. [CrossRef]

20. Swennen, R.; Vuylsteke, D. Aspects of plantain breeding at IITA. In INIBAP Workshop on Sigatoka Leaf Spot Diseases (Mycosphaerella spp.); INIBAP: San Jose, Costa Rica, 1989; pp. 252-266.

21. Ssebuliba, R.; Makumbi, D.; Pillay, M. Patterns of Seed Set in East African Highland Banana (Musa spp.) Hybrids. J. New Seeds 2009, 10, 160-170. [CrossRef]

22. Batte, M.; Swennen, R.; Uwimana, B.; Akech, V.; Brown, A.; Tumuhimbise, R.; Hovmalm, H.P.; Geleta, M.; Ortiz, R. Crossbreeding East African Highland Bananas: Lessons Learnt Relevant to the Botany of the Crop After 21 Years of Genetic Enhancement. Front. Plant Sci. 2019, 10, 81. [CrossRef] [PubMed]

23. Vuylsteke, D.; Ortiz, R.; Ferris, R.S.B.; Crouch, J.H. Plantain Improvement. Plant Breed. Rev. 2010, 14, 267-320. [CrossRef]

24. Waniale, A.; Mukasa, S.; Tugume, A.; Tumuhimbise, R.; Kubiriba, J.; Swennen, R. Glucose performs better than fructose, sucrose, and diluted nectar for germination of banana pollen. Acta Hortic. 2020, 1282, 269-276. [CrossRef]

25. Nyine, M.; Pillay, M. Banana nectar as a medium for testing pollen viability and germination in Musa. Afr. J. Biotechnol. 2007, 6, 1175-1180.

26. Simmonds, N.W. The Evolution of the Bananas; Longmans Green \& Co.: London, UK, 1962.

27. Fortescue, J.; Turner, D. Growth and development of ovules of banana, plantain and enset (Musaceae). Sci. Hortic. 2005, 104, 463-478. [CrossRef]

28. Soares, T.L.; De Souza, E.H.; Costa, M.A.P.D.C.; Silva, S.D.O.E.; Serejo, J.A.D.S. In vivo fertilization of banana. Ciência Rural 2013, 44, 37-42. [CrossRef]

29. Shepherd, K. Seed Fertility of Edible Bananas. J. Hortic. Sci. 1960, 35, 6-20. [CrossRef]

30. Amah, D.; Turner, D.W.; Gibbs, J.D.; Waniale, A.; Gram, G.; Swennen, R. Overcoming the fertility crisis in bananas (Musa spp.). In Achieving Sustainable Cultivation of Bananas Vol 2: Germplasm and Genetic Improvement; Kema, G., Drenth, A., Eds.; Burleigh Dodds Science Publishing: Cambridge, UK, 2020. [CrossRef]

31. Cheng, Y.; Liu, J.; Zhang, H.; Wang, J.; Zhao, Y.; Geng, W. Transcriptome Analysis and Gene Expression Profiling of Abortive and Developing Ovules during Fruit Development in Hazelnut. PLoS ONE 2015, 10, e0122072. [CrossRef]

32. Simmonds, N.W. The Development of the Banana Fruit. J. Exp. Bot. 1953, 4, 87-105. [CrossRef]

33. Simmonds, N.W. Banana fruit development. Nature 1960, 188, 278. [CrossRef] 
34. Vicente, M.R.-S.; Plasencia, J. Salicylic acid beyond defence: Its role in plant growth and development. J. Exp. Bot. 2011, 62, 3321-3338. [CrossRef] [PubMed]

35. An, C.; Mou, Z. Salicylic Acid and its Function in Plant Immunity F. J. Integr. Plant Biol. 2011, 53, 412-428. [CrossRef]

36. Kawano, S.; Yahata, M.; Kunitake, H.; Li, Y. Effect of temperature on self-incompatibility in Citrus pistil and mature pollen culture systems. Acta Hortic. 2016, 117-122. [CrossRef]

37. Yoder, K.; Yuan, R.; Combs, L.; Byers, R.; McFerson, J.; Schmidt, T. Effects of Temperature and the Combination of Liquid Lime Sulfur and Fish Oil on Pollen Germination, Pollen Tube Growth, and Fruit Set in Apples. HortScience 2009, 44, 1277-1283. [CrossRef]

38. Sardos, J.; Rouard, M.; Hueber, Y.; Cenci, A.; Hyma, K.E.; Houwe, I.V.D.; Hřibová, E.; Courtois, B.; Roux, N. A Genome-Wide Association Study on the Seedless Phenotype in Banana (Musa spp.) Reveals the Potential of a Selected Panel to Detect Candidate Genes in a Vegetatively Propagated Crop. PLoS ONE 2016, 11, e0154448. [CrossRef] [PubMed]

39. Jameson, P.E.; Song, J. Cytokinin: A key driver of seed yield. J. Exp. Bot. 2016, 67, 593-606. [CrossRef] [PubMed]

40. Annor, G.A.; Asamoah-Bonti, P.; Sakyi-Dawson, E. Fruit physical characteristics, proximate, mineral and starch characterization of FHIA 19 and FHIA 20 plantain and FHIA 03 cooking banana hybrids. SpringerPlus 2016, 5, 796. [CrossRef] 